\title{
A Lahore Astrolabe of 1587 at Moscow: Enigmas in its Construction
}

\author{
Sergei Maslikov* and Sreeramula Rajeswara Sarma**
}

(Received 29 December 2015; revised 06 August 2016)

\begin{abstract}
The earliest known dated astrolabe in the Indian subcontinent was made in 1567 by Allāhdād at Lahore. The State Museum of Oriental Art at Moscow owns an astrolabe made twenty years later in 1587 at Lahore. An inscription on the front of this astrolabe states that it is a copy of an astrolabe belonging to Mīrzā Bāysunghur. A close examination of the astrolabe shows that there are two different levels in the quality of workmanship. The rete, the alidade and one plate were made by a skilled master. The rest, namely the mater with the geographical gazetteer on the inner side and with the various tables on the back, and four other plates were produced by a person who was not quite familiar with the functions of the astrolabe; these parts do not meet even the minimum requirements of astrolabe construction. This paper provides first a detailed description of the components of the astrolabe and then proceeds to explain the enigmas in its construction. It concludes with a discussion on the possible relationship between the two astrolabes of 1567 and 1587.
\end{abstract}

Key words: Allāhdād, Greenwich Astrolabe, Lahore, Mīrzā Bāysunghur, Moscow Astrolabe, Moscow State Museum of Oriental Art, Ulugh Beg.

\section{INTRODUCTION}

There are about two thousand planispheric astrolabes in museums and private collections all over the world, which were mostly made between ninth and eighteenth centuries. ${ }^{1}$ Each of these is a source of valuable information about the level of scientific knowledge, technology, and artistic preferences at the time of its production. Most astrolabes are preserved in the museums of Great Britain and the United States. Russia made acquaintance with these instruments only in the seventeenth century when everywhere else they were passing out of use. For this reason, the total number of planispheric astrolabes displayed in Russian museums is just 14; on the other hand, there are many surveying instruments of the $18^{\text {th }}-19^{\text {th }}$ centuries, which are traditionally referred to as astrolabes in Russia.

While the museums in St. Petersburg in Russia boast the largest collection of planispheric astrolabes (9 in the State Hermitage, 3 in the Kunstkamera and 1 in the Naval museum), there is only 1 astrolabe in Moscow. It is in the State Museum of Oriental Art and dates back to the sixteenth century. This article is devoted to its study.

This astrolabe was known to be in Astrokhan in 1918; it was acquired by the State Museum of Oriental Art at Moscow in 1939. It was included in the list of scientific instruments drawn

\footnotetext{
* Institute for the History of Science and Technology, Moscow; Director of the Large Novosibirsk Planetarium; A. Nevskogo str. 4-39, Novosibirsk, 630075, Russia; E-mail: s.maslikov@gmail.com ; www.astrolabes.ru .

** Formerly Professor of Sanskrit, Aligarh Muslim University; now Höhenstrasse 28, 40227 Düsseldorf, Germany; E-mail: SR@Sarma.de;www.SRSarma.in.

${ }^{1}$ These are catalogued for the first time by Professor Derek Price and his associates; cf. Gibbs et al (1973).
} 
up by the Soviet historian V. L. Chenakal in 1968 (Chenakal, 1968, p. 43) and in the next year it was described by Smirnov (1969). The Computerized Checklist of Astrolabes records it as follows : 996 15873674160 MBK LAHO (Gibbs et al, 1973, p. 29). It means that the year of production is 996 Hijrī, which corresponds to $1587 \mathrm{AD}$, international number is IC 3674, diameter $160 \mathrm{~mm}$, the place of preservation MBK [Moscow Oriental Museum], and place of production Lahore (India, now Pakistan), which city later became a renowned centre for the production of astrolabes.

The earliest known dated astrolabe from Lahore was created by Allāhdād, the founder of a famous dynasty of astrolabe-makers, in 1567, just 20 years earlier than the object of our study (Sarma, 1996, pp. 7-11, pls. 1-3; Sarma, 2008, p. 204). Therefore, in addition to the description of our astrolabe which will be referred to as "the Moscow astrolabe", we shall attempt to determine its relation to the work of Allāhdād, and, wherever possible, to reconstruct its history.

\section{Description of the Astrolabe}

The astrolabe consists of the following standard components: 1 . the mater with a "throne" and a suspension ring on its top (Fig. 1); 2. the rete with star pointers (Fig. 2); 3. five plates placed under the rete in the cavity of the mater (Figs. 3, 4); and 4. the alidade with sights (Fig. 13). All the

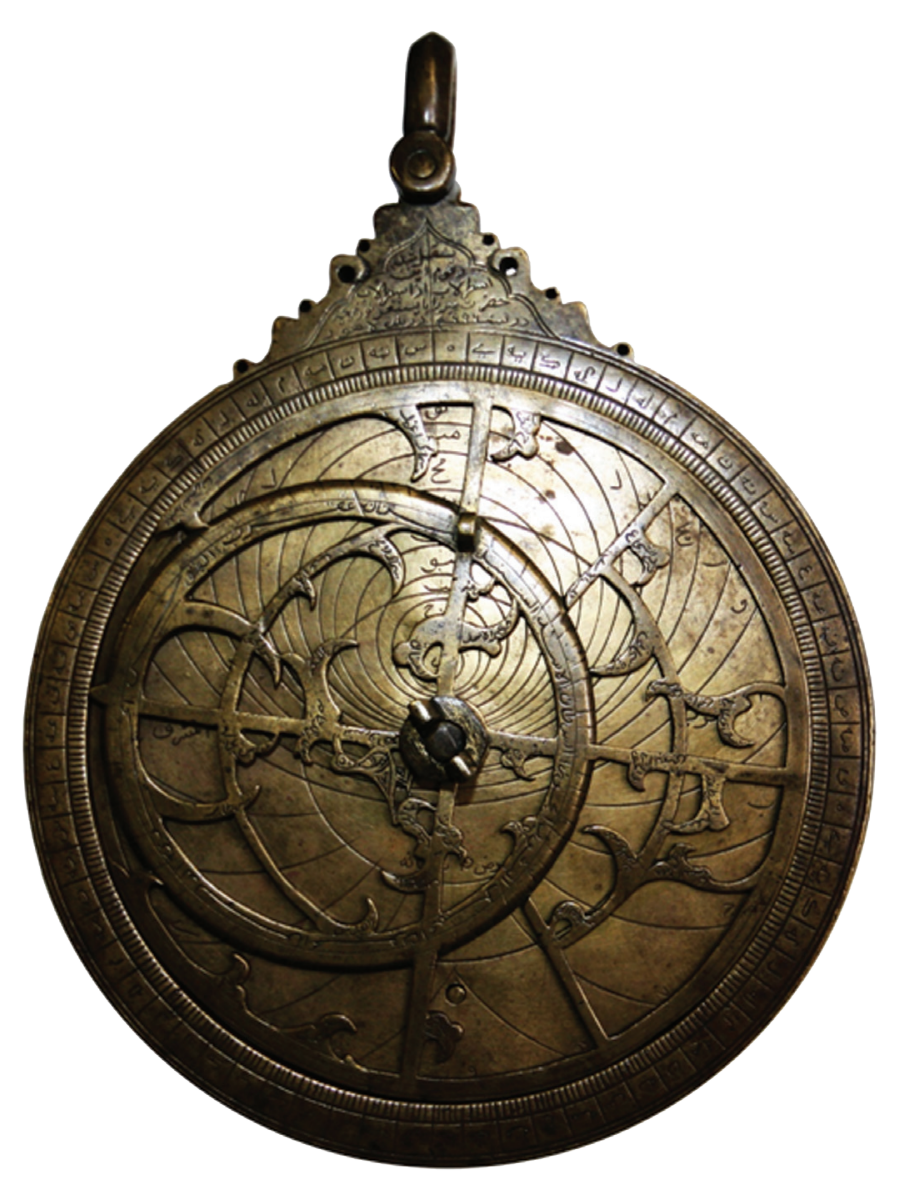

Fig. 1. The front of the Moscow Astrolabe

(C) The State Museum of Oriental Art, Moscow 
parts are held together by a central screw with a slotted nut.

The diameter of the mater is $151 \mathrm{~mm}^{2}$ and its thickness $10.8 \mathrm{~mm}$. The diameter of the rete and of the plates is $128 \mathrm{~mm}$. Each of the five plates is $1.2-1.3 \mathrm{~mm}$ thick. The rete is made of a thicker plate, the thickness of which is $1.7 \mathrm{~mm}$. On the back of the astrolabe, an alidade with two sights is pivoted. The screw and the nut seem to have been added later to the instrument. The total weight of the astrolabe is 1390 gram.

\subsection{The Front}

On the front of the astrolabe there is an inscription on the throne (Fig. 13):

نقل شد رقوم اين اسطر لاب از اسطر لاب حضرث ميرزا بايسنغر نور هري در سنه و9 9 در بلاه لاهور (naql shud ruqūm ayn asturlāb az asṭturlāb haḍat mīrzā bāysunghur nūr hijrī dar sana 996 dar balda lāhür), "The characters (ruqūm, literally numbers) of this astrolabe have been copied (naql) from the astrolabe belonging to Hazrat Mīrzā Bāysunghur in the year 996 Hijrī in the city of Lahore."

This date corresponds to 1587-88 AD. As to the name, there were at least three historical figures bearing the name of Bāysunghur in the fifteenth century. The most famous of them, Giāt al-dīn Bāysunghur (1397-1433), was a grandson of Tamerlane and the youngest son of Shāhrukh Mīrzā. Eventually, he became the mainstay of his father in Herat and was known as a patron of arts and architecture, founder of a library, and a good calligrapher (Encyclopaedia Iranica, vol. IV, 1990, pp. 6-9). Bāysunghur's brother was the astronomer Ulugh Beg who ruled in Samarkand.

The second Bāysunghur, Abul Qāsim Bābur Mīrzā bin Bāysunghur Beg (1422-1457), was the son of the first one and ruled Khurasan from 1449 to 1457 (Jackson, 1986, pp. 108-112). The third one, Bāysunghur Aq Qoyunlu was also one of Tamerlane's descendants and ruled from 1490 to 1493. He was dethroned in Samarkand during the wars waged for power by Bābur, the founder of the Mughal dynasty in India. This Bāysunghur was killed in 905 H (1499/1500) (Bakikhanov, 1991).

The rim of the front is graduated for every degree and numbered in groups of 5 degrees in abjad numbers, running clockwise, as 5, 10, 15, .. $100,5,10,15, \ldots 200,5,10,15, \ldots 300,5$, $10,15, \ldots 60$.

\subsection{The Rete}

The rete of this astrolabe is quite simple. It consists of a counter-changed east-west bar, counter-changed meridian and two arcs of the equator circle and the usual ecliptic and Capricorn circles. The ecliptic is divided into the 12 signs of the zodiac; each sign is graduated for every $6^{\circ}$, but not numbered. There are 33 star pointers with the names of the stars engraved on them. On the ecliptic circle at the end of Virgo, there is a knob for rotating the rete.

Some of the star pointers are shaped like long boots, instead of traditional dagger-shape or flame-shape (nos. 2, 7, 9, 14, 16-20, 22, 27 in Fig. 2). The pointer to the star Vega in constellation Lyra is shaped like the beak of a bird. It carries the Arabic name nasr wāqic, "the falling eagle", but on the present rete the eagle has an unexpectedly peaceful appearance and resembles a duck.

The 33 stars are listed below in Table 1; they are identified on the basis of their Arabic names (Kunitzsch \& Smart, 2006; Allen, 1899) and by measuring their coordinates.

\footnotetext{
${ }^{2}$ Smirnov gives a wrong value of $160 \mathrm{~mm}$ and this value is repeated by Gibbs et.al.,1973 p. 29.
} 


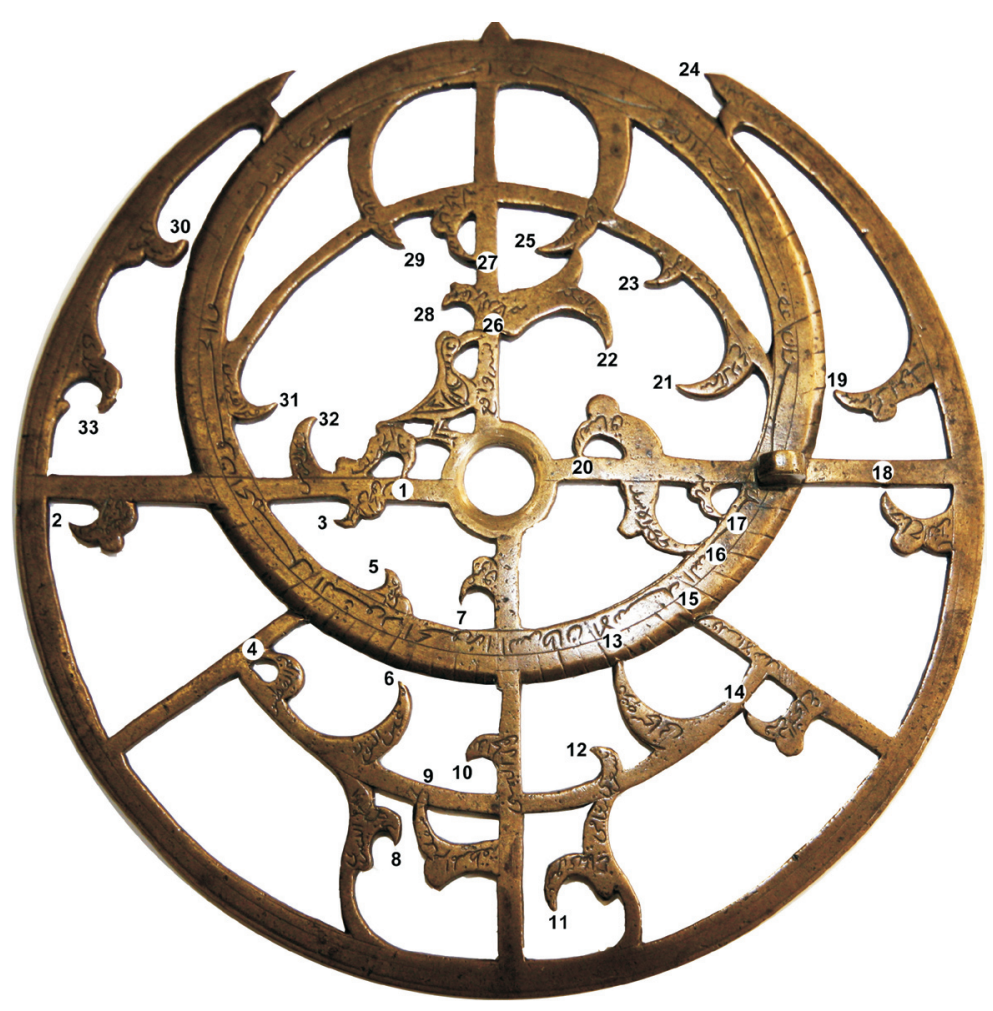

Fig. 2. Rete with the star pointers

(C) The State Museum of Oriental Art, Moscow

Table 1. Stars of the Moscow Astrolabe

\begin{tabular}{|c|c|c|c|c|c|}
\hline$\#$ & $\begin{array}{l}\text { Arabic } \\
\text { Name as } \\
\text { engraved }\end{array}$ & Transliteration & English translation & \multicolumn{2}{|c|}{ Identification } \\
\hline 1 & كف الخضيب| & $k a f f a l-k h a \bar{d} d \bar{\imath} b$ & the stained hand & Caph & $\beta$ Cas \\
\hline 2 & ذنب قيطس & dhanab qaytus [janūbī] & the southern tail of Cetus & Deneb Kaitos & $\beta$ Cet \\
\hline 3 & بطن الحوت & baṭ al-ḥūt & the belly of the fish & Mirach & $\beta$ And \\
\hline 4 & فم القيطس & fam al-qaytus & the mouth of Cetus & - & $\gamma$ Cet \\
\hline 5 & غول & [ra's al-] ghül & [the head of] the Demon & Algol & $\beta$ Per \\
\hline 6 & عين الثور & cayn al-thawr & the eye of the bull & Aldebaran & $\alpha$ Tau \\
\hline 7 & عيوق & ${ }^{c}$ ayyū $q$ & $(?)$ & Capella & $\alpha$ Aur \\
\hline 8 & رجل اليسرى & rijl [...] al-yusrā & the left foot [of the hunter] & Rigel & $\beta$ Ori \\
\hline 9 & مقدم المنطقة & muqaddam al-mințaqa & $\begin{array}{l}\text { first part, beginning of the } \\
\text { belt [of the hunter] }\end{array}$ & Mintaka & $\delta$ Ori \\
\hline 10 & يد الجوز ايمنى & yad al-jawz $\bar{a}$ 'yumnā & the right hand of the hunter & Betelgeuse & $\alpha$ Ori \\
\hline 11 & شعرى يماني & shicrā yamānī [yyah] & the southern Sirius & Sirius & $\alpha \mathrm{CMa}$ \\
\hline 12 & شتعرى شامي & shicrā sha'āmī [yyah] & the northern Sirius & Procyon & $\alpha \mathrm{CMi}$ \\
\hline 13 & نثرة سحابح & nathra sahāa $\bar{b}$ & $\begin{array}{l}\text { nathra-the tip of the } \\
\text { [lion's] nose, sahāb } \bar{\imath}-a \\
\text { nebulous [star] }\end{array}$ & $\begin{array}{l}\text { Beehive } \\
\text { Cluster } \\
\text { (Praesepe) } \\
\end{array}$ & $\varepsilon \mathrm{Cnc}$ \\
\hline 14 & فرد الشجاع| & fard al-shuj $\bar{a}^{c}$ & $\begin{array}{l}\text { the solitary one of the water } \\
\text { snake }\end{array}$ & Alphard & $\alpha$ Hya \\
\hline 15 & قلب الأسد & qalb al-asad & the lion's heart & Regulus & $\alpha$ Leo \\
\hline
\end{tabular}




\begin{tabular}{|c|c|c|c|c|c|}
\hline 16 & ظهر الأسد & zahr al-asad & the lion's back & Zosma, Dhur & $\delta$ Leo \\
\hline 17 & صر فة & sarfa & the changer [of the weather] & Denebola & $\beta$ Leo \\
\hline 18 & جناح الغراب & janāh al-ghurāb & the raven's wing & Gienah & $\gamma \mathrm{Crv}$ \\
\hline 19 & سمك اعزل & $\operatorname{simāk}[a l]-a^{c} z a l$ & the unarmed simāk & Spica & $\alpha$ Vir \\
\hline 20 & العناق & al-canāq & the badger (a desert animal) & Mizar & $\zeta \mathrm{UMa}$ \\
\hline 21 & سماك رامح & simāk rāmih & simāk armed with a lance & Arcturus & $\alpha$ Boo \\
\hline 22 & نير الفكة & nayyir al-fakka & $\begin{array}{l}\text { the bright one of the broken } \\
\text { vessel }\end{array}$ & Alphecca & $\alpha \mathrm{CrB}$ \\
\hline 23 & عنق الحية & ${ }^{c}$ unuq al-hayya & the serpent's neck & Unukalhai & $\alpha$ Ser \\
\hline 24 & قلب العقرب & qalb al-caqrab & the scorpion's heart & Antares & $\alpha \operatorname{Sco}$ \\
\hline 25 & رأس الحوا & ra's al-hawwā', & head of the snake-charmer & Rasalhague & $\alpha \mathrm{Oph}$ \\
\hline 26 & نسر و اقع & nasr [al]-wāqi ${ }^{c}$ & the swooping eagle & Vega & $\alpha \operatorname{Lyr}$ \\
\hline 27 & رأس الجاتئي & ra's al-jāthō & head of the kneeling one & Rasalgethi & $\alpha$ Her \\
\hline 28 & منقار الاجاجة & minqār al-dajāja & the hen's beak & Albireo & $\beta$ Cyg \\
\hline 29 & نسر طائر & nasr țā'ir & the flying eagle & Altair & $\alpha \mathrm{Aql}$ \\
\hline 30 & ذنب الحوت & dhanab al-hūt & tail of the fish ${ }^{3}$ & Deneb Algedi & $\delta$ Cap \\
\hline 31 & فم الفرس & fam al-faras & the horse's mouth & $\begin{array}{l}\text { Enif } \\
(\text { Markab) }\end{array}$ & $\begin{array}{l}\varepsilon \mathrm{Peg}^{4} \\
(\alpha \mathrm{Peg})\end{array}$ \\
\hline 32 & منكب الفرس & mankib al-faras & the horse's shoulder & Scheat & $\beta$ Peg \\
\hline 33 & ذنب الجدي & dhanab al-jadī & the tail of the goat & Ident. with 30 & $\delta$ Cap \\
\hline
\end{tabular}

Special measurements were carried out to control the identification, test the accuracy of the rete, and determine the epoch of stellar coordinates. For each pointer, the radius $r$ and mediation $m$ were measured. Then we calculated the equatorial coordinates $\alpha$ and $\delta$ of each star by the formulas:

$$
\operatorname{tg}\left[\left(90^{\circ}-\delta\right) / 2\right]=r / r_{e}, \operatorname{tg} \alpha=\operatorname{tg} m \cdot \cos \varepsilon,
$$

where $r_{e}$ is the radius of the equator, $\varepsilon$ is

Table 2. Measurement and calculation of the Stars' positions (degrees)

\begin{tabular}{|l|c|c|c|c|c|c|c|c|c|c|}
\hline & & \multicolumn{3}{|c|}{ Measur. \& calcul. } & \multicolumn{3}{|c|}{ Longitude } & \multicolumn{3}{c|}{ Latitude } \\
\hline & Star & $\delta$ & $\mathrm{m}$ & $\alpha$ & Astrolabe & Ulugh Beg & $\Delta$ & Astrolabe & Ulugh Beg & $\Delta$ \\
\hline 1 & $\beta$ Cas & $55.9^{\circ}$ & $0^{\circ}$ & $0^{\circ}$ & $30.4^{\circ}$ & $28^{\circ} 1$ & $2.4^{\circ}$ & $49.4^{\circ}$ & $50^{\circ} 48^{\prime}$ & $-1.4^{\circ}$ \\
\hline 2 & $\beta$ Cet & -19.4 & 11 & 10.1 & 1.2 & 35521 & 5.9 & -21.7 & -210 & -0.7 \\
\hline 3 & $\beta$ And & 32.5 & 16 & 14.7 & 26.7 & 2313 & 3.5 & 24.1 & 2536 & -1.5 \\
\hline 4 & $\gamma$ Cet & 1.9 & 38 & 35.6 & 33.9 & 3210 & 1.7 & -11.6 & -1218 & 0.7 \\
\hline 5 & $\beta$ Per & 39.9 & 42 & 39.5 & 49.9 & 4855 & 1.0 & 23.2 & 22 & 1.2 \\
\hline 6 & $\alpha$ Tau & 18.9 & 66 & 64.1 & 65.6 & 6231 & 3.1 & -2.4 & -515 & 2.8 \\
\hline 7 & $\alpha$ Aur & 44.5 & 75 & 73.7 & 77.6 & 7443 & 2.9 & 21.8 & 2242 & -0.9 \\
\hline
\end{tabular}

the obliquity of the ecliptic $\left(23^{\circ} 30^{\prime}\right)$. The next step was to calculate ecliptic coordinates - longitude and latitude - and compare the obtained values with those prevalent the in 15th-16th centuries in the Zìj-i Jadìd-i Sultāni (Zīj-i Gurganī). This Zìj is often referred to as Zīj-i Mìrzza Ulugh Bīk, as it was compiled in 1437 by Samarqand astronomers supervised by Ulugh Beg (1394-1449) (Kennedy, 1956, pp. 3-4, pp. 44-45). (Table 2.)

3 (\#30) apparently, in this case the fish is Capricornus.

${ }^{4}$ Pointer \#31 corresponds to $\alpha$ Peg by coordinates, but by name it is $\varepsilon$ Peg. 


\begin{tabular}{|c|c|c|c|c|c|c|c|c|c|c|}
\hline 8 & $\beta$ Ori & -10.0 & 75 & 73.7 & 70.9 & 6925 & 1.5 & -32.4 & -3118 & -1.1 \\
\hline 9 & $\delta$ Ori & -1.0 & 77 & 75.9 & 74.6 & 7434 & 0 & -23.7 & -2357 & 0.2 \\
\hline 10 & $\alpha$ Ori & 6.3 & 84 & 83.5 & 83.2 & 8113 & 2.0 & -17 & -1645 & 0.2 \\
\hline 11 & $\alpha \mathrm{CMa}$ & -17.0 & 96 & 96.5 & 98.1 & 9619 & 1.8 & -40.3 & -3930 & -0.8 \\
\hline 12 & $\alpha \mathrm{CMi}$ & 5.8 & 107 & 108.4 & 109.1 & 10822 & 0.7 & -16.4 & -160 & -0.4 \\
\hline 13 & $\varepsilon \mathrm{Cnc}$ & 20.5 & 122 & 124.3 & 121.9 & 11946 & 2.1 & 0.8 & 10 & 0.2 \\
\hline 14 & $\alpha$ Hya & -4.0 & 135 & 137.5 & 141.2 & 13931 & 1.7 & -19.4 & -2230 & 3.1 \\
\hline 15 & $\alpha$ Leo & 13.9 & 142 & 143.0 & 140.8 & 14213 & -1.4 & -0.7 & 09 & -0.9 \\
\hline 16 & $\delta$ Leo & 20.5 & 160 & 160.5 & 154.2 & 15328 & 0.7 & 11.4 & 149 & -2.7 \\
\hline 17 & $\beta$ Leo & 15.7 & 170 & 170.7 & 165.2 & 16349 & 1.4 & 10.7 & 120 & -1.3 \\
\hline 18 & $\gamma \mathrm{Crv}$ & -13.4 & 180 & 180 & 185.4 & 18246 & 2.6 & -12.3 & -1418 & 2.0 \\
\hline 19 & $\alpha$ Vir & -9.0 & 197 & 196 & 198.2 & 19610 & 2.0 & -2 & -29 & 0.1 \\
\hline 20 & $\zeta \mathrm{UMa}$ & 57.6 & 198 & 197.3 & 159 & 1584 & 0.9 & 56.9 & 5612 & 0.7 \\
\hline 21 & $\alpha$ Boo & 21.1 & 210 & 208 & 197.4 & 19631 & 0.9 & 30.3 & 3118 & -1.0 \\
\hline 22 & $\alpha \mathrm{CrB}$ & 29.7 & 232 & 229.6 & 216.0 & 21434 & 1.4 & 45.9 & 4430 & 1.4 \\
\hline 23 & $\alpha$ Ser & 10.0 & 236 & 233.7 & 228.5 & 22425 & 4.1 & 28.4 & 2548 & 2.6 \\
\hline 24 & $\alpha$ Sco & -25.1 & 244 & 242 & 244.8 & 24028 & 4.3 & -4.1 & -345 & -0.3 \\
\hline 25 & $\alpha \mathrm{Oph}$ & 12.8 & 261 & 260.2 & 258.2 & 25513 & 3.0 & 35.8 & 3551 & -0.1 \\
\hline 26 & $\alpha \operatorname{Lyr}$ & 37.6 & 274 & 274.4 & 277.2 & 27819 & -1.1 & 60.9 & 62 & -1.1 \\
\hline 27 & $\alpha$ Her & 15.1 & 275 & 275.5 & 276.8 & 24755 & 28.9 & 38.4 & 3730 & 0.9 \\
\hline 28 & $\beta$ Cyg & 27.0 & 287 & 288.4 & 295.3 & 29425 & 0.9 & 48.8 & 4912 & -0.4 \\
\hline 29 & $\alpha \mathrm{Aql}$ & 9.0 & 291 & 292.7 & 296.2 & 29410 & 2.0 & 30.4 & 2915 & 1.1 \\
\hline 30 & $\delta$ Cap & -16.8 & 320 & 322 & 319 & 31528 & 3.5 & -1.8 & -215 & 0.4 \\
\hline 31 & $\alpha$ Peg & 13.9 & 340 & 340.5 & 347.6 & 34555 & 1.7 & 20.4 & 190 & 1.4 \\
\hline 32 & $\beta$ Peg & 25.0 & 340 & 340.5 & 352.7 & 35137 & 1.1 & 30.5 & 3051 & -0.3 \\
\hline 33 & $\delta$ Cap & -16.8 & 350 & 350.7 & 344.8 & 31413 & 30.6 & -11.8 & -230 & 9.3 \\
\hline
\end{tabular}

The performed calculations suggest the following conclusions:

1. The manufacturing precision of the pointers is rather high; for the latitude it is about 1.1 degrees, which shows the work of an experienced maker.

2. Due to precession, longitudes of stars in the astrolabe are higher than Ulugh Beg's longitudes on average by 1.4 degrees. At that time, as a rule, permanent precession of 1 degree per 66 years was normally used, so the epoch of the astrolabe stars is about a hundred years later than Ulugh Beg's $z \bar{j} j$ (1437). This date - about $\mathbf{1 5 3 7}$ - is beyond the life span of all the Bāysunghurs. The source of the star coordinates might have been some $z \bar{l} j$ of this period based on Ulugh Beg's catalogue (but not necessarily so).
3. For stars no. 27 and 33, error in longitude is about 30 degrees, which indicates a possible error in the sign of the zodiac. This mistake was committed either by the author of the original $z \bar{j} j$ or by the maker.

The rete of the Moscow astrolabe will be compared with the retes of other astrolabes made in Lahore over the same period in the last part of this article.

\subsection{The Plates}

In the cavity of the mater, there are five plates. All the plates have a small hole in the lower part of the meridian line, into which fits the knob protruding in the same position on the inner side of the mater. Both the sides of each plate are engraved with altitude circles, azimuth arcs and hour lines as shown in Table 3. The two sides of each plate are designated by letters "a" and " $b$ ". 
Table 3. Plates and their sides

\begin{tabular}{|c|c|c|c|c|}
\hline Sides & Latitude & $\begin{array}{l}\text { Maximum } \\
\text { Day length } \\
\text { on the plate }\end{array}$ & $\begin{array}{l}\mathrm{Mc} \\
\mathrm{Da} \\
\text { in }\end{array}$ & $\begin{array}{l}\text { um } \\
\text { rgth } \\
\text { re }\end{array}$ \\
\hline $\mathrm{Ia}$ & $21^{\circ} 40^{\prime}$ & $14 \mathrm{hrs} 20 \mathrm{~min}$ & $13 \mathrm{~h}$ & $\min$ \\
\hline $\mathrm{Ib}$ & \multicolumn{4}{|l|}{ Horizons } \\
\hline IIa & $12^{\circ}$ & 14 & 12 & 43 \\
\hline $\mathrm{IIb}$ & $32^{\circ}$ & 14 & 14 & 07 \\
\hline IIIa & $30^{\circ}$ & 58 & 13 & 57 \\
\hline IIIb & $46^{\circ}$ & 40 & 15 & 35 \\
\hline $\mathrm{IVa}$ & $36^{\circ}$ & 30 & 14 & 28 \\
\hline $\mathrm{IVb}$ & $54^{\circ}$ & 20 & 16 & 55 \\
\hline $\mathrm{Va}$ & $42^{\circ}$ & 14 & 15 & 05 \\
\hline $\mathrm{Vb}$ & $50^{\circ}$ & 58 & 16 & 11 \\
\hline
\end{tabular}

The obverse side of the first plate (Fig. 3) is engraved for the latitude of Mecca. The altitude circles are drawn for every $6^{\circ}$ and numbered in abjad notation on both sides of the meridian. The curves of azimuths are drawn below the horizon line for every $10^{\circ}$ and numbered. There are plain lines for unequal hours and dotted lines for the equal hours which are also numbered. In the middle of the plate is engraved makka al-card 2140 (Mecca, the latitude of $21^{\circ} 40^{\prime}$ ) and $s \bar{a}^{c} \bar{a} t$ 1420 (the hours of the longest day $14 \mathrm{hrs} 20 \mathrm{~min}$ ). The second value is wrong. It should be $13 \mathrm{hrs}$ $20 \mathrm{~min}$.

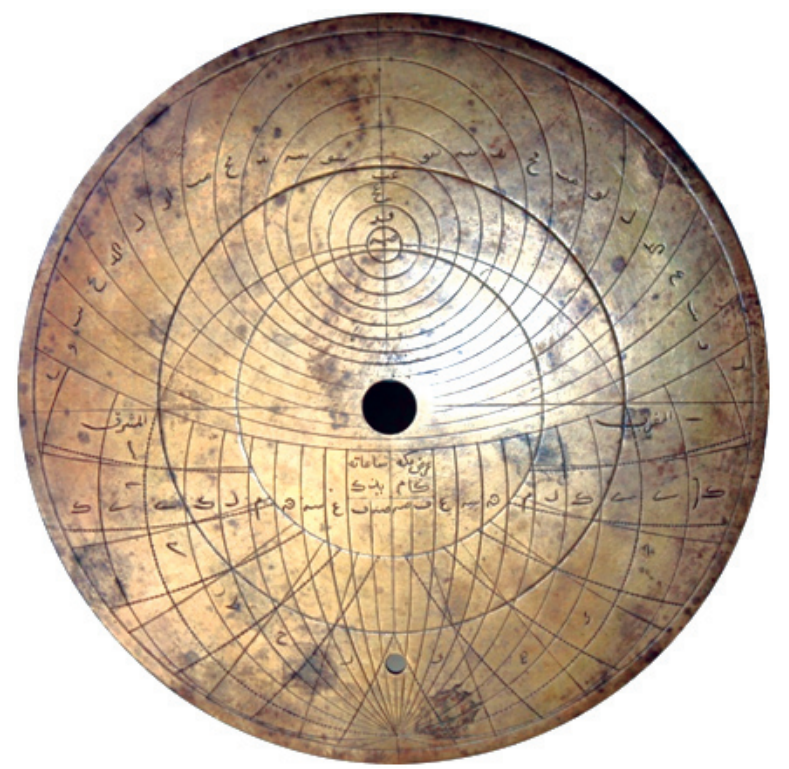

Fig. 3. Plate Ia for Mecca

(C) The State Museum of Oriental Art, Moscow
The reverse side (Fig. 4) is engraved with four sets of half horizons. These horizons allow one to make certain astronomical calculations for places at different latitudes, even for those latitudes for which there is no separate plate in the astrolabe. This plate is convenient for compiling tables. Such a plate was first introduced by Habash al-Hāsib in the ninth century and later it became a standard component under the name safịha âfāq $\bar{\imath}$ (Morrison, 2007, p. 64).

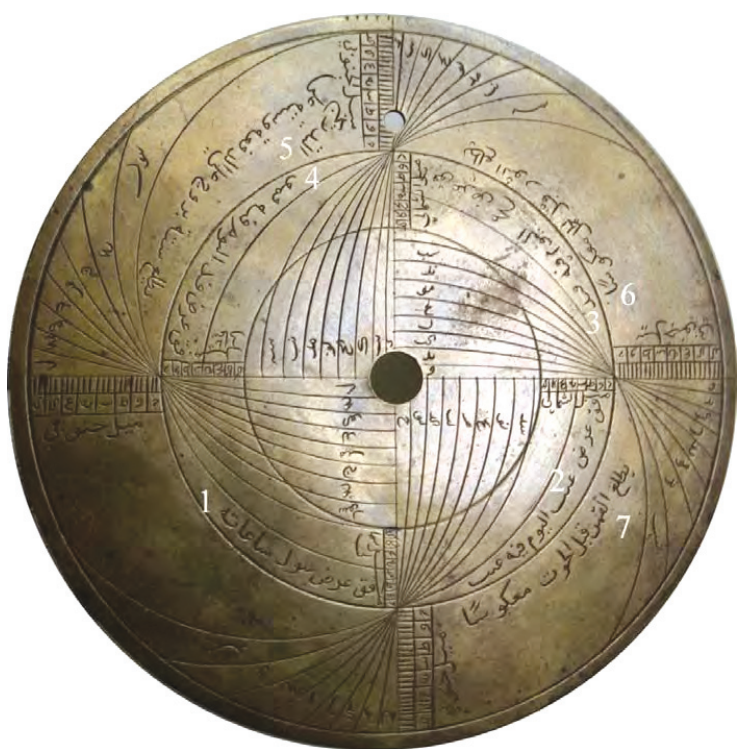

Fig. 4. Plate Ib with multiple horizons

(C) The State Museum of Oriental Art, Moscow

In the present plate, there are four sets of half-horizons for latitudes between $4^{\circ}$ and $66^{\circ}$, arranged at intervals of 8 degrees in the following manner:

$\begin{array}{llllllll}4 & 12 & 20 & 28 & 36 & 44 & 52 & 60 \\ 6 & 14 & 22 & 30 & 38 & 46 & 54 & 62 \\ 8 & 16 & 24 & 32 & 40 & 48 & 56 & 64 \\ 10 & 18 & 26 & 34 & 42 & 50 & 58 & 66\end{array}$

In addition, there is an extra half-horizon in each of the four quadrants, accompanied by labels as shown below.

\footnotetext{
${ }^{5}$ King (2005): 931. Day length values calculated with $\varepsilon=23^{\circ} 35^{\prime}$.
} 
1. Half-horizon for $66 ; 30^{\circ}$; below it is engraved

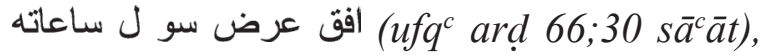
"horizon of the latitude $66 ; 30^{\circ}$; hours [of the longest day at this latitude]". The label does not mention the hours; they should be 24 .

2. Half-horizon for $72^{\circ}$; below it is engraved افق عرض عب اليوم فيه عب (ufq ${ }^{c}$ ard 72 al-yawm fi 72), "horizon of the latitude $72^{\circ}$; the day is $72 "$.

3. Half-horizon for $78^{\circ}$; below it is engraved افق عرض عح اليوم فيه قيد, (ufq card 78 al-yawm fi 114), "horizon of the latitude $78^{\circ}$; the day is $114 "$.

4. Half-horizon for $84^{\circ}$; below it is engraved افق عرض فد اليوم فيه قمو , (ufq card 84 al-yawm fi 146), "horizon of the latitude $84^{\circ}$; the day is $146 "$ ".

An astrolabe made by Yusuf ibn Hājjī al-J̄̄lānī in 1522 [now at the National Maritime Museum, Greenwich (Charette, 2005, p. 222)], which will be discussed below, has a similar horizon plate, with these four extra half-horizons with almost the same labels. In his description of this astrolabe, François Charette explains the labels as follows: "We should understand the expression 'the day is ...' as meaning 'the number of days in a year with a 24-hour daylight is ....",

Accordingly, at latitude $72^{\circ}$, there are 72 days in a year with a 24-hours daylight; at latitude $78^{\circ}$, there are 114 days in a year with a 24-hours daylight; and at latitude $84^{\circ}$, there are 146 days in a year with a 24-hours daylight, [and at latitude $90^{\circ}$, there are 180 days in a year with a 24-hours daylight]. But these figures are not very accurate. The correct figures are given in the following table 4.

Furthermore, there are three more inscriptions outside the circle of equator (which are not found on the astrolabe of 1522):

5. Below the half-horizon for latitude $84^{\circ}$ is written يطلع ستة بروج على الدفعة و ستة على التذريج, (yatlac sitta burūj ${ }^{c}$ ali al-duf́ a wa sittac alī al-tadrīj), "six [zodiacal] signs rise simultaneously and [the other] six [signs] gradually".

6. Below the half-horizon for latitude $78^{\circ}$ is written يطلع الثور قبل الحمل معكوسا (yatla althawr qabl al-hamal mac kūsā), "Taurus rises before Aries inversely".

7. Below the half-horizon for latitude $72^{\circ}$ is written يطلع القمر [الحمل؟] قبل الحوت دعكوسا (yatlac al-qamar [al-hamal] qabl al-hūt mackūsā), "the moon [Aries?] rises before Pisces inversely".

These statements are highly intriguing and rather incomprehensible. At latitude $84^{\circ}$, the six signs ascend from Aries to Virgo. What is stated in 6 and 7 with regard to the latitudes $72^{\circ}$ and $78^{\circ}$ is not clear. The correct position is shown in the table 5. below.

Table 4. Occurrence of 24-hours daylight at higher latitudes

\begin{tabular}{|l|c|c|c|c|}
\hline Latitude & $\begin{array}{c}\text { Declination } \\
\text { of the Sun } \\
\text { (minimum) }\end{array}$ & $\begin{array}{c}\text { Occurrence of 24- } \\
\text { hours } \\
\text { daylight }\end{array}$ & $\begin{array}{c}\text { Number of days } \\
\text { with 24-hours } \\
\text { daylight in theory }\end{array}$ & $\begin{array}{c}\text { Number of days } \\
\text { mentioned on the } \\
\text { horizon plate }\end{array}$ \\
\hline $66^{\circ} 30^{\prime}$ & $+23^{\circ} 30^{\circ}$ & 22 June only & 1 & - \\
\hline $72^{\circ}$ & $+18^{\circ}$ & 12 May-2 August & 122 & 72 \\
\hline $78^{\circ}$ & $+12^{\circ}$ & 22 April-22 August & 156 & 114 \\
\hline $84^{\circ}$ & $+6^{\circ}$ & 5 April - 8 September & 146 \\
\hline
\end{tabular}


Table 5. Risings of the Signs at higher latitudes

\begin{tabular}{|l|l|l|l|l|l|}
\hline & Longitude & Declination & Latitude 72 & Latitude 78 & Latitude 84 \\
\hline Aries & 0 & 0 & rises & rises & rises \\
\hline Taurus & 30 & +1130 & rises & rises & rises \\
\hline Gemini & 60 & +2010 & rises & rises & rises \\
\hline Cancer & 90 & +2330 & rises & rises & rises \\
\hline Leo & 120 & +2010 & rises & rises & rises \\
\hline Virgo & 150 & +1130 & rises & rises & rises \\
\hline Libra & 180 & 0 & rises & rises & partly rises \\
\hline Scorpio & 210 & -1130 & partly rises & partly rises & never rises \\
\hline Sagittarius & 240 & -2010 & never rises & never rises & never rises \\
\hline Capricorn & 270 & -2330 & never rises & never rises & never rises \\
\hline Aquarius & 300 & -2010 & partly rises & partly rises & never rises \\
\hline Pisces & 330 & -1130 & rises & rises & partly rises \\
\hline
\end{tabular}

There are also four sets of declination scales along the four radii inside and outside the circle of equator, divided in $1^{\circ}$ and $3^{\circ}$ and numbered from 3 to 24 with the labels mayl shamā $\bar{l} \bar{l}$ (northern declination) inside the equator and mayl janūbi (southern declination) outside the equator.

While plate I was made reasonably correctly, the remaining four plates are absolutely non-functional. They were made without compliance with the rules, "by eye," as the saying goes. The centres of the altitude circles are

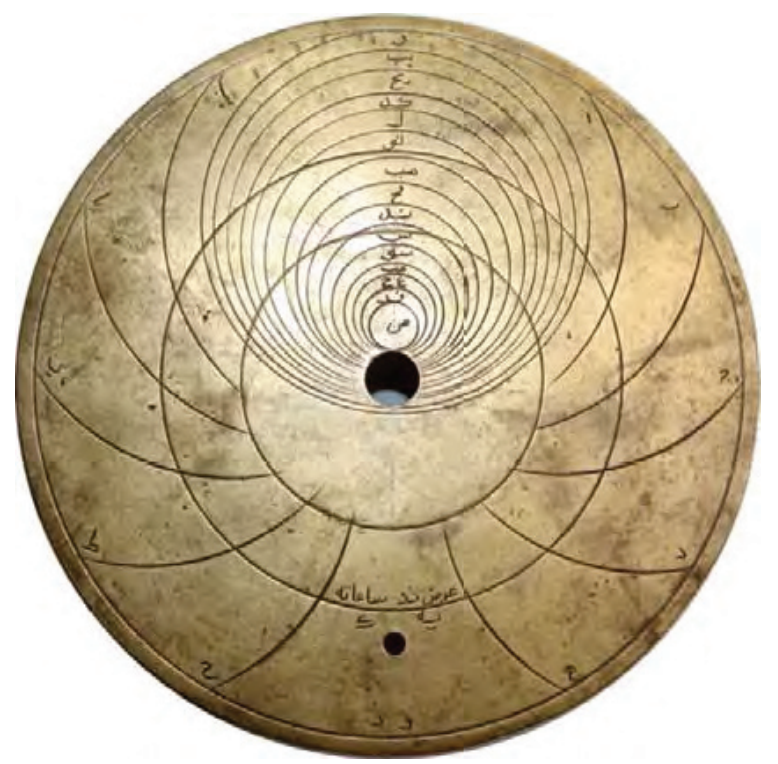

positioned inaccurately. The latitudes mentioned on the plates do not match the locations of the centres, the circles are inscribed incorrectly, the maximum duration of the day does not match the latitude, and so on. The maker of the plates seems to have been ignorant about the rules of this work. Obviously, the first plate is strikingly different from the rest of them. It was made by an experienced astrolabist and demonstrates strict adherence to all canons (except for the wrong length of the day).

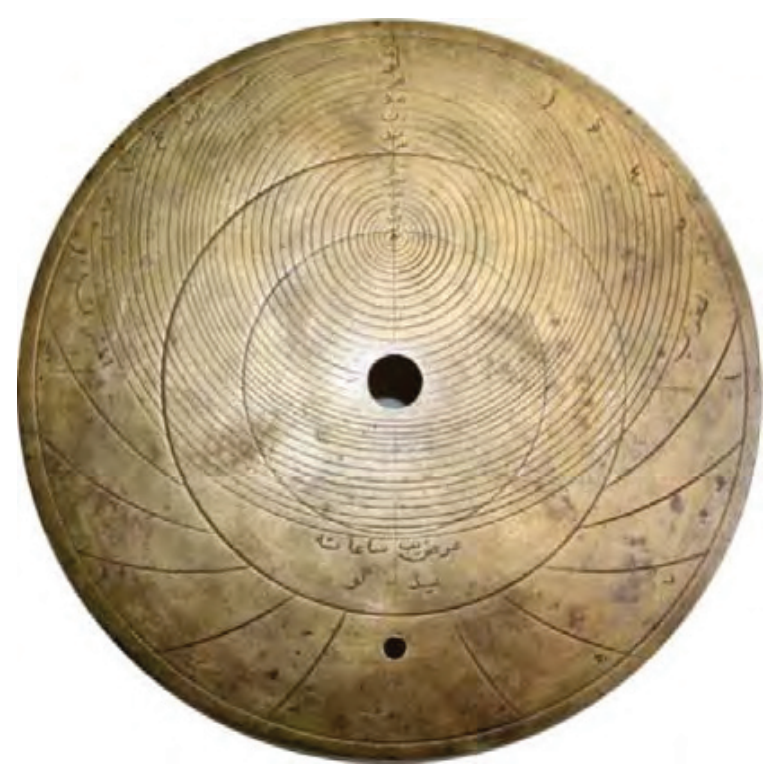

Fig. 5. Plate IVb and Plate IIa

(C) The State Museum of Oriental Art, Moscow 
Two examples will suffice to show the incompetence of the maker of the remaining plates. On plate IVb, which is on the left in Fig. 5, the horizon touches the Capricorn circle. This is possible only at latitude $67^{\circ}$ and not at latitude $54^{\circ}$ for which the plate is said to have been designed. On plate IIa, which is on the right in Fig. 5, all the altitude circles are drawn from the same centre which is at the zenith. This violates the rules of stereographic projection. Moreover, the zenith is placed on the Cancer circle. This corresponds to latitude $23^{\circ}$, and not to $12^{\circ}$ as written on the plate.

\subsection{The Geographical Gazetteer}

A geographical gazetteer with the names, longitudes, latitudes and qibla of 84 places is engraved on the inner surface of the mater. The numbers are inscribed in the Persian version of abjad notation; the notation of some figures is different from the classical inscriptions, for instance, number 20 is $s$ instead of 5 . There are zero digits in the gazetteers, which are indicated by a sign resembling an inverted letter "ayn". This sign is not found on other 16th-century astrolabes.

The longitudes of cities were counted, according to the tradition dating back to Ptolemy, from the mythical Isles of Fortune situated around 35-36 degrees to the west of the Greenwich meridian. For example, the longitude of the Iranian city of Isfahan is $51^{\circ} 29^{\prime}$. The astrolabe shows the value of $86^{\circ} 40^{\prime}$, the difference is $35^{\circ} 11^{\prime}$. Qibla, the direction that should be faced when a Muslim prays, which is fixed as the direction of the Kaaba in Mecca, was not given for all cities; it was engraved only wherever there was space.

On the left half of the mater between the rows of the coordinates, the engraver, for no apparent reason, copied the inscription from the front of the throne once again (it is encircled by us in white colour in Fig. 7): dar 996 در 99 هري مرقوم شد نقل از اسطر لاب بايسنغر hijrī marqūm shud naql az asturlāb bāysunghur), "in the year 996 Hijrī the copy was inscribed from the astrolabe of Bāysunghur”.

There ought to have been three circles, each consisting of four rows to accommodate the place names, longitudes, latitudes and qibla respectively. This gazetteer violated the symmetry and broke the circular arrangement of the rows on the left and right sides (see Fig. 6). No such distortion can be seen on any other Arabic astrolabe!

The argument $($ buldān $=$ cities; $t \bar{u} l=$ longitude: ${ }^{c}$ ar $\underline{d}=$ latitude; inhira $\bar{f}=$ the angle of orientation towards Mecca, or qibla) is engraved, correctly, on the left at the top (encircled in red). This should have been followed immediately by Mecca and its coordinates, but these were engraved below the argument. Four localities are duplicated (Balkh, nos. 46 and 74; Kājerūn, nos. 53 and 82; Khujand, nos. 47 and 77; Aden, nos. 36 and 67 ), so that there are actually 83 cities in the table, out of which only 26 have a qibla.

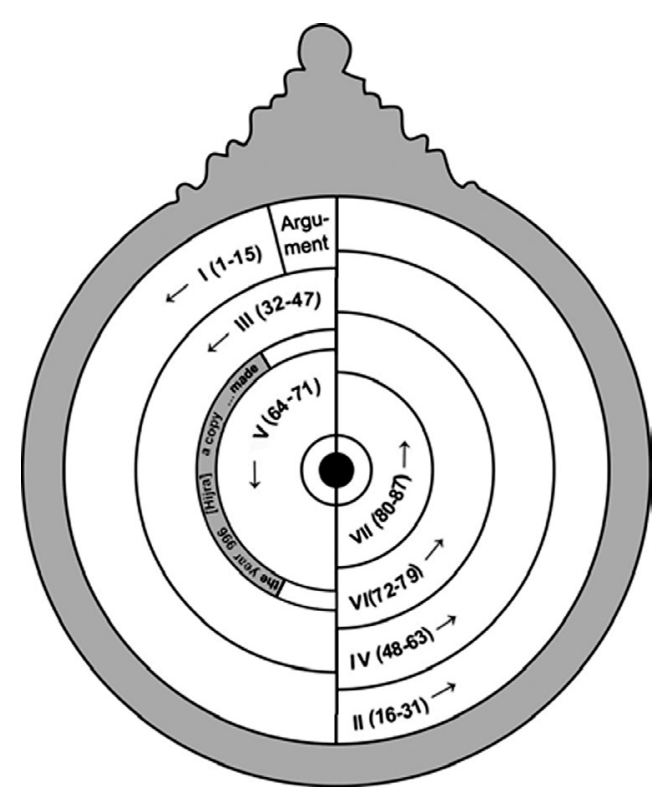

Fig. 6. Diagram showing the dislocation of the circular rows in the gazetteer 


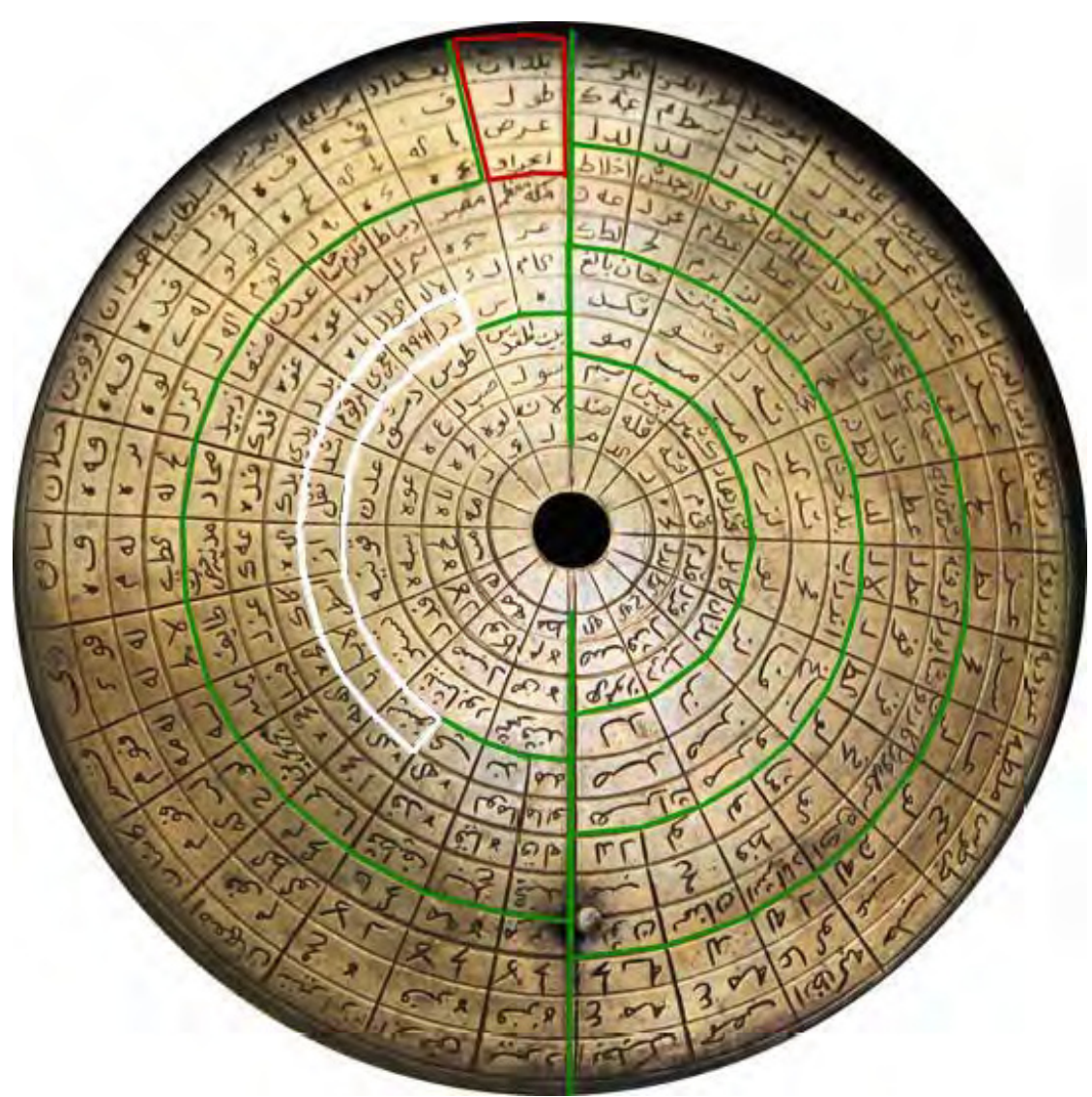

Fig. 7. The geographical gazetteer (coloured lines are added by us) (C) The State Museum of Oriental Art, Moscow

Table 6. The geographical gazetteer ${ }^{6}$

\begin{tabular}{|c|c|c|c|c|c|}
\hline & \multicolumn{2}{|l|}{ Place Name } & Longitude & Latitude & Inhirāf \\
\hline \multicolumn{6}{|c|}{ Row I } \\
\hline 1 & Baghdād & بغداد & $80^{\circ} 0^{\prime}$ & $33^{\circ} 25^{\prime}$ & $13^{\circ} 0^{\prime}$ \\
\hline 2 & Marāgha & مر اغه & 820 & 3720 & 1550 \\
\hline 3 & Tabrīz & تبريز & 820 & 380 & 1530 \\
\hline 4 & Sulțāniya & سلطانيه & 8330 & 3636 & 2640 \\
\hline 5 & Hamadān & همدان & 840 & 3510 & 2530 \\
\hline 6 & Qazwīn & قزوين & 850 & 360 & 2730 \\
\hline 7 & Jilān (Gilan) & جلان & 85 & 370 & 2835 \\
\hline 8 & Sāwa & ساوه & 850 & 350 & [39] 57 \\
\hline 9 & Rayy (Tehran) & נى & 8620 & 3535 & 3133 \\
\hline 10 & Qum & قم & 8640 & {$[35] 45$} & 35 \\
\hline 11 & Kāshān & كاشان & 8640 & {$[32] 25$} & 368 \\
\hline
\end{tabular}

\footnotetext{
${ }^{6}$ Names of localities in square brackets are doubtful. Numbers in square brackets are incorrect values of coordinates. Cf. Gibbs
} \& Saliba (1984):192-200. 


\begin{tabular}{|c|c|c|c|c|c|}
\hline 12 & Ișfahān & اصفهان & 8640 & [29] 26 & 4023 \\
\hline 13 & Shīrāz & شيراز & 880 & 3130 & 5123 \\
\hline 14 & Abarqūh & ابرقوه & 840 & 3113 & 450 \\
\hline 15 & Yazd & يزد & 870 & 3113 & 4717 \\
\hline \multicolumn{6}{|c|}{ Row II } \\
\hline 16 & Bacalbek $^{\mathrm{c}}$ & بعلبكى & 7045 & 3315 & \\
\hline 17 & Hims (Homs) & حمص & 7045 & 34 & \\
\hline 18 & Antākya & انطاكيه & 7126 & 3530 & \\
\hline 19 & Halab (Alleppo) & حلب & 72 & 3550 & \\
\hline 20 & Tartūs & طرطوس & 68 & 36 & \\
\hline 21 & Malatiya & ملطيه & 71 & 37 & \\
\hline 22 & Ammūriya & امور ائة & 64 & 43 & \\
\hline 23 & Erzurūm & ارزروم & 77 & 39 & \\
\hline 24 & Erzincān & ارزنكان & 74 & 38 & \\
\hline 25 & Rās al--'Ayn & راس العين & 74 & 36 & \\
\hline 26 & Mārdīn & ماردين & 74 & 37 & \\
\hline 27 & Nușāybin & نصابن & 75 & 37 & \\
\hline 28 & ${ }^{\mathrm{C} A \bar{n} \mathrm{n}}$ & عانه & 7630 & 34 & \\
\hline 29 & Mūșil (Mosul) & موصل & 77 & 3430 & \\
\hline 30 & Țarābulus (Tripoli) & طر ابلس & 6940 & 34 & \\
\hline 31 & Tikrīt & تكريت & 7520 & 3430 & \\
\hline \multicolumn{6}{|c|}{ Row III } \\
\hline 32 & $\begin{array}{l}\text { Makka Mukarramah } \\
\text { (Mecca) }\end{array}$ & مكه مكرمه & 77 & 2140 & \\
\hline 33 & Misr (Egypt) & مصر & 630 & 3020 & \\
\hline 34 & Damietta & دمياط & 6330 & 3130 & \\
\hline 35 & Qulzum Sāḥā & قُلزم ساحا & 640 & 2930 & \\
\hline 36 & ${ }^{\mathrm{c}}$ Adan (Aden) & عدن & 760 & 110 & \\
\hline 37 & SSanacāa $^{c}$ & صنعا & 760 & 1430 & \\
\hline 38 & Zabīd & زبيد & 8420 & 1410 & \\
\hline 39 & Șuhār & صحار & 840 & 1420 & \\
\hline 40 & Madīna (Medina) & مدئة & 7520 & 250 & \\
\hline 41 & Ṭāyif & طايف & 7730 & 2120 & \\
\hline 42 & Yamāma & يمامة & 8230 & 230 & \\
\hline 43 & Jahīn & جحئن & 830 & 2515 & \\
\hline 44 & Lahsā & لحسا & 8330 & 240 & \\
\hline 45 & Qațīf & قطيف & 840 & 250 & 20 \\
\hline 46 & Balkh & بلخ & 101 & 3641 & 54 \\
\hline 47 & Khujand & خجند & 10035 & 4136 & 45 \\
\hline \multicolumn{6}{|c|}{ Row IV } \\
\hline 48 & Tūn & تون & 92 & 3430 & \\
\hline 49 & Samnān & سمنان & 83 & 36 & \\
\hline
\end{tabular}




\begin{tabular}{|c|c|c|c|c|c|}
\hline 50 & Astarābād & استر اباد & 89 & 36 & \\
\hline 51 & [qut] (Quwait ?) & اكت & 82 & 26 & \\
\hline 52 & [Sūfard] & (?) سوفرد & 88 & 36 & \\
\hline 53 & Kāzirūn & كازرون & 87 & 29 & \\
\hline 54 & Shābūr & شابور & 86 & 30 & \\
\hline 55 & Kūfa & كوفه & 7930 & 3130 & \\
\hline 56 & Sāmarrā & (?) سامَرَّاء & 79 & 34 & \\
\hline 57 & Shamākhī & شاخي & 8430 & 3950 & \\
\hline 58 & Nakhjiwān & نخجوان & 81 & 38 & \\
\hline 59 & Marand & مرند & 80 & 37 & \\
\hline 60 & Salamās & سلماس & 79 & 37 & \\
\hline 61 & Khoy & خوى & 7940 & 3740 & \\
\hline 62 & [Arjāshan] & ارجاشن & 7730 & 38 & \\
\hline 63 & Akhlāt & اخلاط & 7550 & 3920 & \\
\hline \multicolumn{6}{|c|}{ Row V } \\
\hline 64 & Bayt al-Maqdis & بيث المقدس & 6630 & 3150 & 30 \\
\hline 65 & Ṭūs & طوس & 9230 & 36 & 45 \\
\hline 66 & Dimashq & دمشق & 700 & 330 & 30 \\
\hline 67 & ${ }^{\mathrm{c} A d a n}$ (Aden) & عدن & 76 & 11 & 45 \\
\hline 68 & Konya & قونيه & 690 & 380 & 42 \\
\hline 69 & Shustar & شستر & 8430 & 3130 & 35 \\
\hline 70 & Nīshābūr & نيشابور & 8230 & 3621 & 45 \\
\hline 71 & Samarqand & سمرقند & 90 & 400 & 49 \\
\hline \multicolumn{6}{|c|}{ Row VI } \\
\hline 72 & Herāt & هرات & 94 & 3030 & \\
\hline 73 & Marw & هرو & 97 & 37 & \\
\hline 74 & Balkh & بلخ & 101 & 37 & \\
\hline 75 & Andarāb & اندر اب & 83 & 36 & \\
\hline 76 & Badakhshān & بلخشان & 10424 & 3410 & \\
\hline 77 & Khujand & خجند & 10530 & 42 & \\
\hline 78 & Khutan & ختن & 86 & 42 & \\
\hline 79 & Khānbāligh (Beijing) & خانبالغ & 124 & 46 & \\
\hline \multicolumn{6}{|c|}{ Row VII } \\
\hline 80 & Hurmūz (Ormuz) & هرموز & 92 & 25 & \\
\hline 81 & Daibal & دييل & 8230 & 2520 & \\
\hline 82 & Qājirān & قازران & 8730 & 29 & \\
\hline 83 & Kābul & كابل & 10440 & 3430 & \\
\hline 84 & Qandahār & قتندهار & 10040 & 33 & \\
\hline 85 & Kashmir & كشمر & 105 & 30 & \\
\hline 86 & Chīn (China) & جين & 135 & 24 & \\
\hline 87 & [?] & L (?) & 9230 & 40 & \\
\hline
\end{tabular}


It is interesting to look at the geographical distribution of these localities, which shows the main trade routes much before the Safavid Empire.
In this gazetteer, there are no western cities of the Maghreb countries, no Indian cities, and, there is no Lahore.

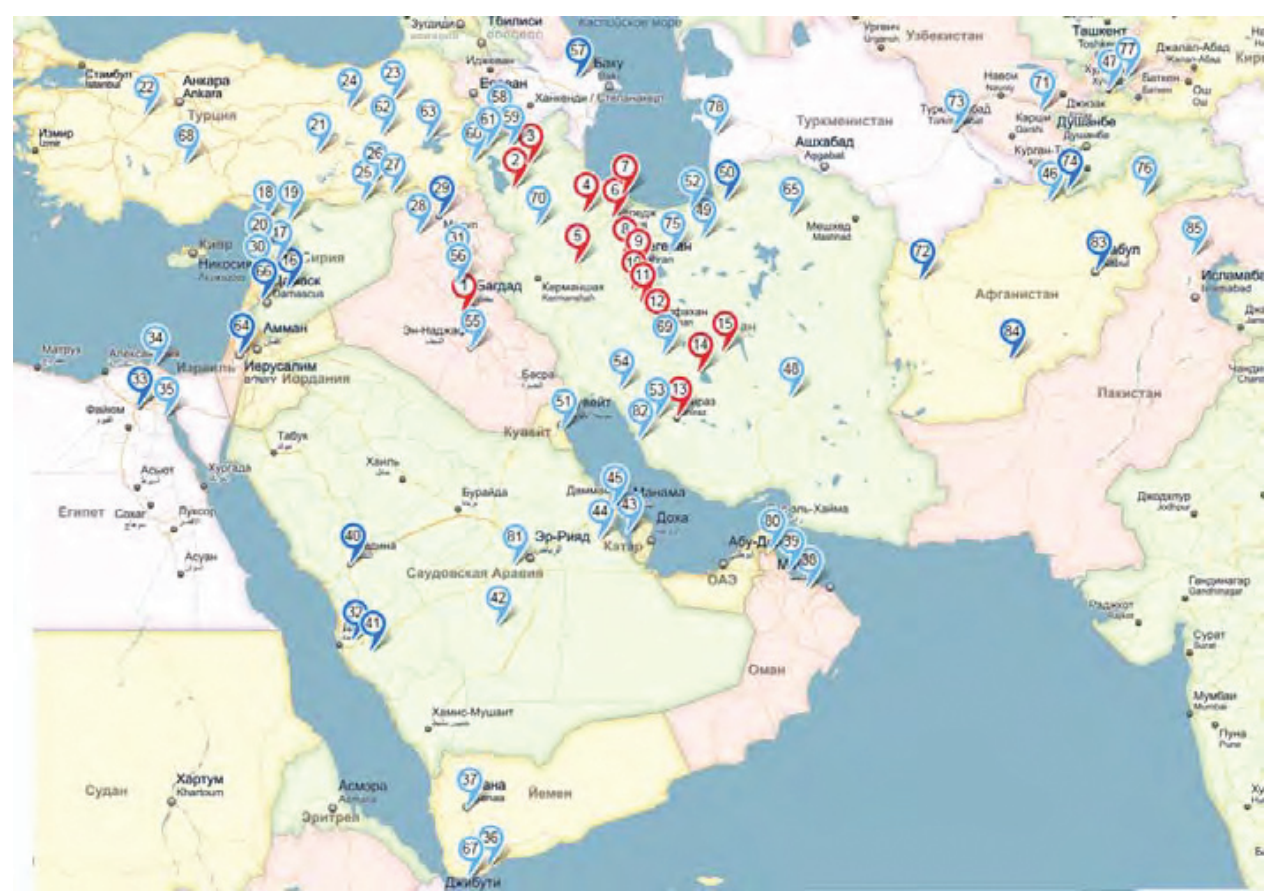

Fig. 8. Distribution of cities featured in the gazetteer. The first 15 cities are highlighted in red. Two easternmost Chinese cities (nos. 79 and 86), which somehow happen to be in the list, are not shown here.

\subsection{The Back of the Astrolabe}

On the reverse side (back) of the astrolabe there is an inscription on the throne which reads لصاحبه السعادة والسلامة, (l'sāhab al-sacāda wa al-c alläma), "may happiness and peace be with the owner of this [astrolabe]".

On the upper half of the rim are engraved the altitude scales divided in $1^{\circ}$ and $5^{\circ}$. These are numbered separately on the left and right from 5 to 90 .

In the upper left quadrant there is a Sine scale. It usually consists of 60 horizontal lines. In our case, there are more lines than necessary, namely 67 . This scale can be used with the help of the alidade (see Fig. 9).

In the upper-right quadrant, it is customary to draw the declination arcs. Instead there is a pitiful hint of a shadow square, which is usually placed in the lower half of the back. The scales are broken and not functional because they are drawn incorrectly. In addition, two astrological tables are inserted here.

The first is the table of triplicities and their day and night ruling planets. In this scheme, the 12 signs of the zodiac are grouped into 4 sets of 3 signs each, so that in each set, the signs are $120^{\circ}$ apart. The signs are ruled by different planetary rulers in the daytime and at night. The scheme follows the tradition of the first century astrologer Dorotheus of Sidon who wrote an instructional poem on astrology in Greek in five books. There are similar tables on several Arab astrolabes from the Museum of Greenwich (Ackermann, 2005, pp. 80-81) and also on the Lahore astrolabes (Kaye, 1918, pp. 119-126). When the table of triplicities is engraved on the astrolabe, the signs are represented by their serial numbers in abjad 


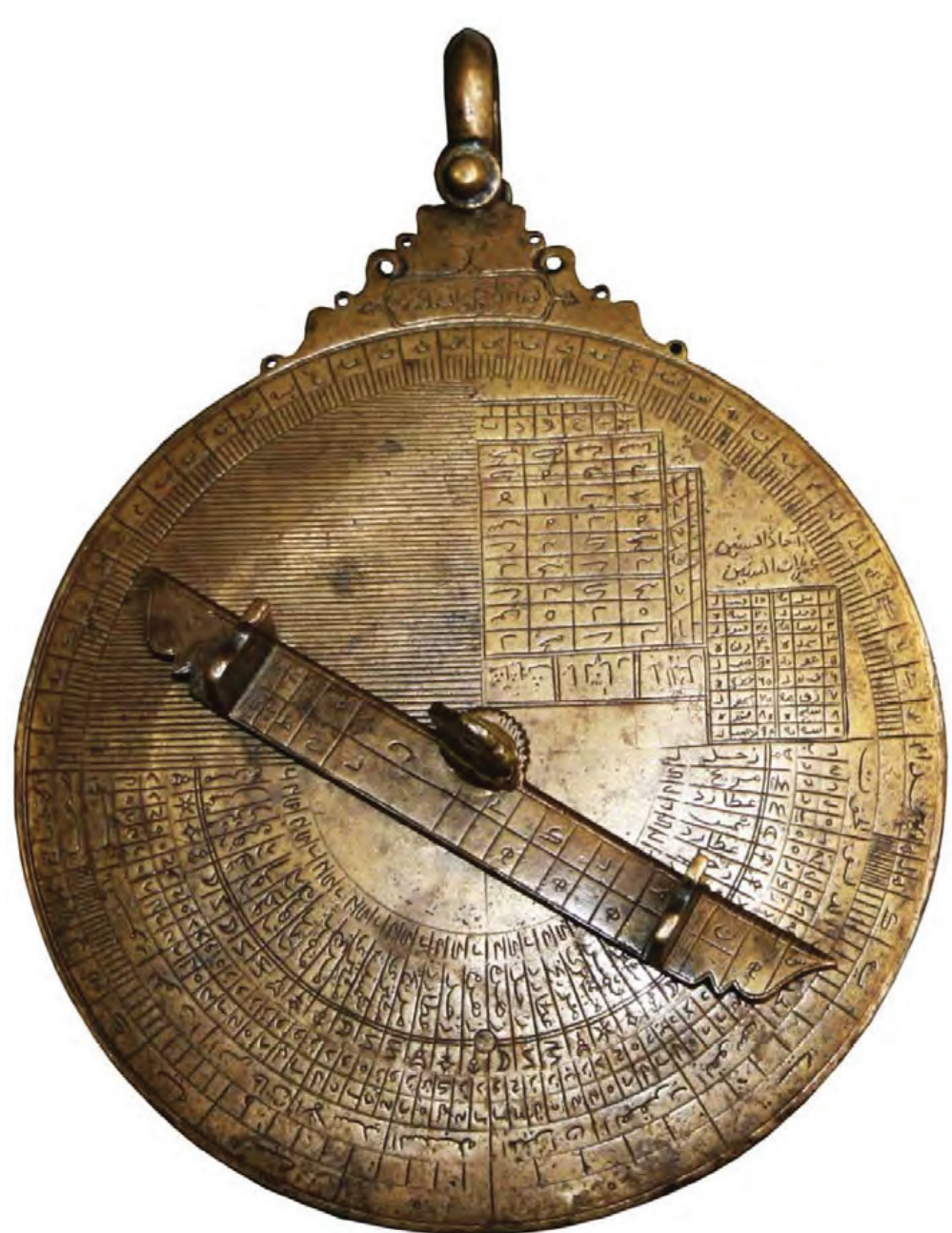

Fig. 9. The back of the astrolabe (C) The State Museum of Oriental Art, Moscow

notation from 0 to 11 and the planets by the last letter of their Arabic name. The four sets are

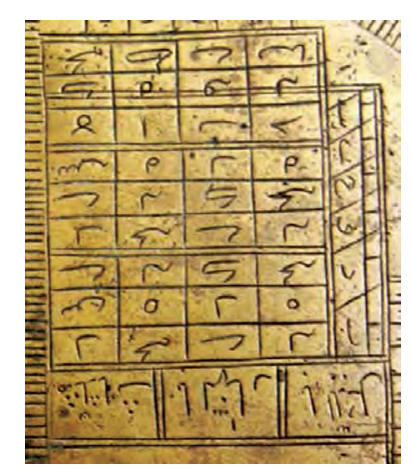

Fig. 10. Table of Triplicities engraved upside down (on the right there is a fragment of the shadow square with numbers $2,4,6,8,10,12)$. Detail of Fig. 9. assigned to the four elements: Aries, Leo and Sagittarius $(0,4,8)$ to the "fire"; Taurus, Virgo and Capricorn $(1,5,9)$ to the "earth"; Gemini, Libra and Aquarius $(2,6,10)$ to the "air"; Cancer, Scorpio and Pisces $(3,7,11)$ to the "water".

The astrolabe maker engraved the table upside-down as shown in Fig. 10. The row containing the argument is at the bottom. It reads muthallathāt (triplicities), bi al-nahār (in the day) and bi al-layal (at night). Actually the argument should have been in a column on the right of the table. Moreover, in the table the triplicities should have been shown first and not the planetary rulers of the day. 
We reproduce below the table of triplicities after rearranging it properly.

Table 7. Triplicities

\begin{tabular}{|c|c|c|c|c|}
\hline \multirow{3}{*}{ The triplicities } & 0 Aries & 1 Taurus & 2 Gemini & 3 Cancer \\
\hline & 4 Leo & 5 Virgo & 6 Libra & 7 Scorpio \\
\hline & 8 Sagittarius & 9 Capricorn & 10 Aquarius & 11 Pisces \\
\hline \multirow[t]{3}{*}{ Ruling planets by day } & س Sun & - Venus & \Saturn & - Venus \\
\hline & $<$ Jupiter & J Moon & $\checkmark$ Mercury & $\dot{\tau}$ Mars \\
\hline & J Saturn & $\dot{\tau}$ Mars & $\angle$ Jupiter & JMoon \\
\hline \multirow{3}{*}{$\begin{array}{l}\text { Ruling planets at } \\
\text { night }\end{array}$} & $<$ Jupiter & J Moon & $\checkmark$ Mercury & $\dot{\tau}$ Mars \\
\hline & س Sun & - Venus & \Saturn & - Venus \\
\hline & J Saturn & $\dot{\tau}$ Mars & $\angle$ Jupiter & JMoon \\
\hline
\end{tabular}

The second table engraved on the upper right quadrant is usually designated as $f a d l$ al-dawr (excess of revolution); it a kind of Calendar Table. Unlike the previous table, this one is correctly placed. It shows the excess of the duration of the average year over the integer number of days. For example, one tropical year exceeds the integer number of days 365 by 5 hours 48 minutes 59 seconds. This excess corresponds to 87 degrees 15 minutes. The table shows the multiples of this value, from 1 to 90 . In the first column on the right are the numbers 1 to 9 in common Arabic/Persian numerals; in the second and third columns are the multiples of excess in degrees and minutes respectively. Again in the fourth column are the decades 10 to 90 and in the next two columns, the corresponding multiples of the excess. There is a similar table, for example, on a Persian astrolabe made by a representative of Kirmānī family two centuries earlier, in 1388 (Pingree, 2009, pp. 42-47). This table can also be found on many Lahore astrolabes.

Above the table are two lines of writing. It is not the name of the table, but the argument. The first line reads آحاد اسلين(âhād aslīn), "units of years"; this should have been written in the table above the first three columns on the right where the multiples are in units. The second line reads عثرداث اسلين ('ashar däth aslìn), "tens of years": this should have been written in the table above the fourth, fifth and sixth columns where the multiples are in tens.

We believe that the purpose of this table may be as follows. It could be intended for the calculation of the so-called "solar returns" in casting the annual horoscope of the "native". Such a horoscope was cast for the moment when the sun returned to the same position on the ecliptic where it was at the birth of "native". At that time, the "stakes" of the birth horoscope the so-called "upper mid-heaven" and the "lower mid-heaven" (i.e., the two intersections of the ecliptic and the meridian) - will be displaced by the amount of the excess. The values of the table cover the man's possible life span from 1 to 99 years. The calculation procedure was described, for instance, by al-Khwārizmī in the 33rd chapter

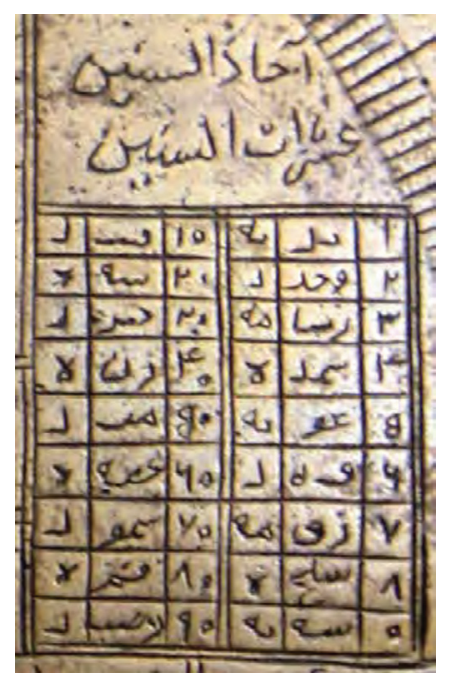

Fig. 11. The Calendar Table (detail of Fig. 9) 
of the "Treatise on using an astrolabe" more than a thousand years ago. ${ }^{7}$

Table 8. Excess of Revolution

\begin{tabular}{|c|c|c|c|c|c|}
\hline 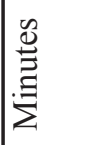 & 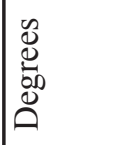 & 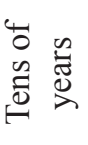 & 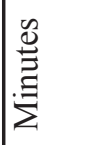 & 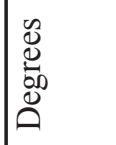 & 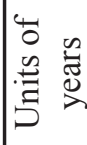 \\
\hline 30 & 152 & 10 & 15 & 87 & 1 \\
\hline 0 & 305 & 20 & 30 & 174 & 2 \\
\hline 30 & 97 & 30 & 45 & 261 & 3 \\
\hline 0 & 250 & 40 & 0 & 349 & 4 \\
\hline 30 & 42 & 50 & 15 & 76 & 5 \\
\hline 0 & 195 & 60 & 30 & 163 & 6 \\
\hline 30 & 347 & 70 & 45 & 250 & 7 \\
\hline 0 & 140 & 80 & 0 & 338 & 8 \\
\hline 30 & 292 & 90 & 15 & 65 & 9 \\
\hline
\end{tabular}

Let us now consider scales in the lower halfof the back. For convenience, they are numbered from the outer periphery upto the centre by Roman numerals from I to VIII.
In the lower part on the edge of the limb, there are two Cotangent scales. The inscription on the left says $a l-a s \bar{a} b i c$, i.e. "fingers" and on the right "al-aqdām", i.e. "feet". The values of the function are to be taken in a duodecimal system on the left and in a septenary system on the right. For instance, $\operatorname{ctg} 60^{\circ}=0.577($ decimal system $)=$ $7 / 12($ duodecimal $)=4 / 7$ (septenary). The scale on the left reading is not 7 , as it should be, but about 7.7. The scale on the right reading is not 4 , as it should be, but 5 . This implies the low accuracy of the scales.

The Zodiacal scale (scale III) containing the names of the 12 signs, starts on the left side and proceeds counter-clockwise.

The Terms (scales IV and V) show the division of each sign of the zodiac into five unequal parts. The Ruling planets are designated by the last letter of their Arabic name, as in the

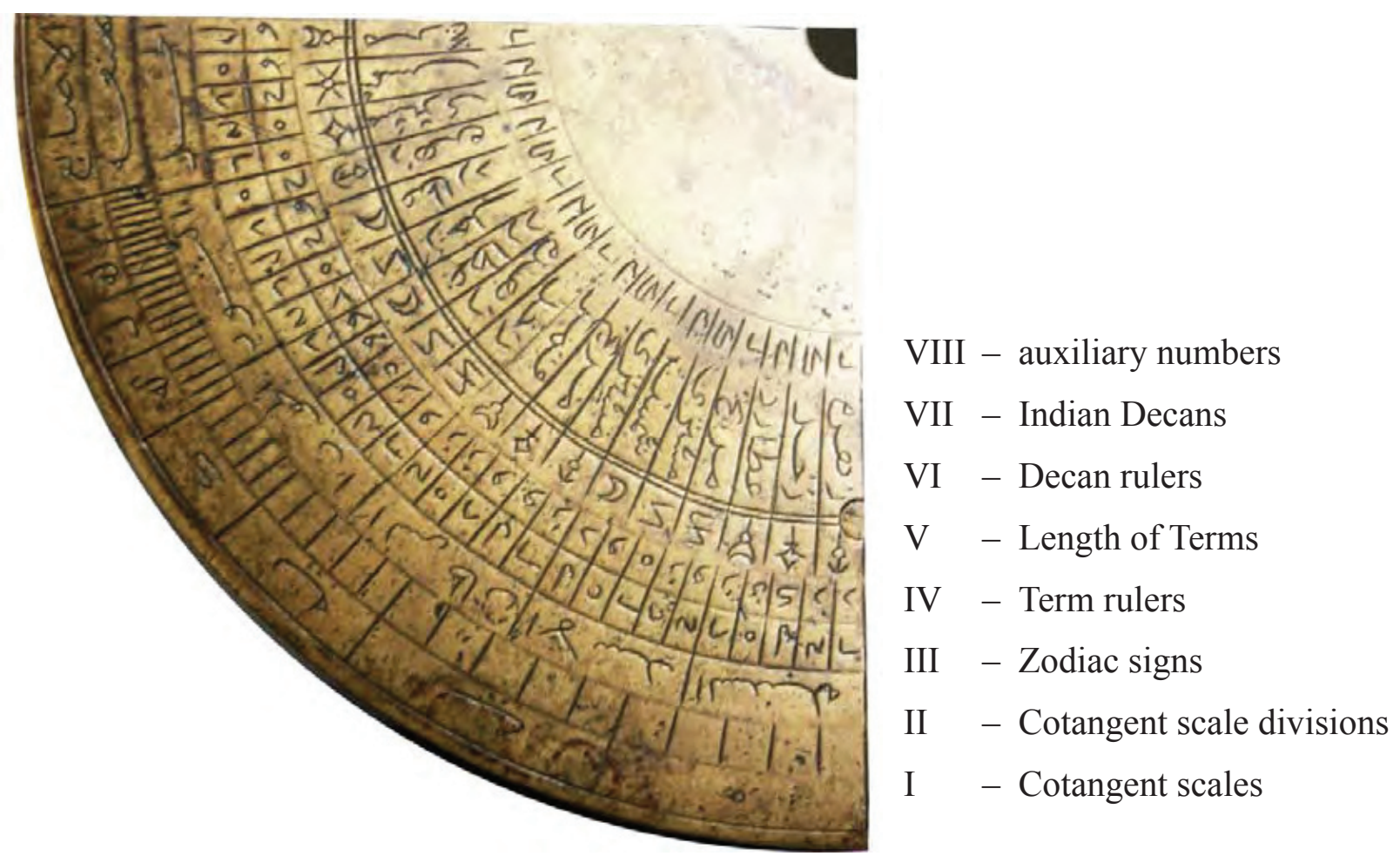

Fig. 12. Scales on the lower half of the back (detail of Fig.9)

\footnotetext{
${ }^{7}$ al-Khwārizmī (1983): 263. Al-Khwārizmī used an excess equal to 93 degrees, which corresponds to the sidereal year, the time taken by the Earth to orbit the Sun once with respect to the fixed zodiac sign (without precession).
} 
table of triplicities. The method for division that we find here goes back to Ptolemy's Tetrabiblos. Ptolemy himself called this method Egyptian since it dates back to Nechepsos and Petrosiris (151 BC). There are several instruments with such scales in the collection of the Greenwich museum. (Ackermann, 2005, pp.79-80) This table also occurs in many Lahore astrolabes.

Table 9. The scale of Terms. Correct values are given in square brackets.

\begin{tabular}{|c|c|c|}
\hline Zodiac sign & $\begin{array}{c}\text { Ruling } \\
\text { planet } \\
\text { (scale IV) }\end{array}$ & $\begin{array}{c}\text { Term } \\
\text { length } \\
\text { (scale V) }\end{array}$ \\
\hline \multirow{5}{*}{ Aries } & Jupiter & 6 \\
\hline & Venus & 6 \\
\hline & Mercury & 8 \\
\hline & Mars & 5 \\
\hline & Saturn & 5 \\
\hline \multirow{5}{*}{ Taurus } & Venus & 8 \\
\hline & Mercury & 6 \\
\hline & Jupiter & 8 \\
\hline & Saturn & 5 \\
\hline & Mars & 3 \\
\hline \multirow{5}{*}{ Gemini } & Mercury & 6 \\
\hline & Jupiter & 6 \\
\hline & Venus & 5 \\
\hline & Mars & 7 \\
\hline & Saturn & 6 \\
\hline \multirow{5}{*}{ Cancer } & Mars & 7 \\
\hline & Venus & $7[6]$ \\
\hline & Mercury & 6 \\
\hline & Jupiter & $6[7]$ \\
\hline & Saturn & $7[4]$ \\
\hline \multirow{5}{*}{ Leo } & Jupiter & $4[6]$ \\
\hline & Venus & $6[5]$ \\
\hline & Saturn & $5[7]$ \\
\hline & Mercury & $7[6]$ \\
\hline & Mars & 6 \\
\hline \multirow{5}{*}{ Virgo } & Mercury & 7 \\
\hline & Venus & 10 \\
\hline & Jupiter & $8[4]$ \\
\hline & Mars & 7 \\
\hline & Saturn & $4[2]$ \\
\hline
\end{tabular}

\begin{tabular}{|c|c|c|}
\hline \multirow{5}{*}{ Libra } & Saturn & 6 \\
\hline & Mercury & 8 \\
\hline & Jupiter & 7 \\
\hline & Venus & 7 \\
\hline & Mars & 2 \\
\hline \multirow{5}{*}{ Scorpio } & Mars & 7 \\
\hline & Venus & 4 \\
\hline & Mercury & 8 \\
\hline & Jupiter & 5 \\
\hline & Saturn & 6 \\
\hline \multirow{5}{*}{ Sagittarius } & Jupiter & 12 \\
\hline & Venus & 5 \\
\hline & Mercury & 4 \\
\hline & Saturn & $4[5]$ \\
\hline & Mars & 4 \\
\hline \multirow{4}{*}{ Capricorn } & Mercury & 7 \\
\hline & Jupiter & 7 \\
\hline & Venus & 8 \\
\hline & Saturn & 4 \\
\hline \multirow{6}{*}{ Aquarius } & Mars & 4 \\
\hline & Mercury & 7 \\
\hline & Venus & 6 \\
\hline & Jupiter & 7 \\
\hline & Mars & 5 \\
\hline & Saturn & 5 \\
\hline \multirow{5}{*}{ Pisces } & Venus & 12 \\
\hline & Jupiter & 4 \\
\hline & Mercury & 3 \\
\hline & Mars & 4 [9] \\
\hline & Saturn & 2 \\
\hline
\end{tabular}

The Faces (or Decans). This division of each sign of the zodiac into three equal parts of 10 degrees is of Chaldean origin and was transmitted to India through Greek treatises in the third to the sixth centuries. Scale VII shows the so-called classical Indian system. Full Arabic names of the planets are given here: mirrīkh (Mars), al-shams (Sun), al-mushtarī (Jupiter), al-zuhra (Venus), cuṭāid (Mercury), zuhal (Saturn), and al-qamar (Moon). Next to them the numbers 10, 20, 30 are shown, for convenience, making up scale VIII. 
On scale VI, there is a symbol of a ruling planet for each decan: Mercury $\not{\xi}$, Sun *, Venus $\hat{\uparrow}$, Mars $\hat{\uparrow}$, Moon $\mathbb{C}$, Saturn S, Jupiter ङ. The system here corresponds neither to the Chaldean numerology system (with ruling planets alternating according to the "Star of the Magi"), nor to "Astronomica" by Marcus Manilius (Mars, Sun, Jupiter in Aries, Leo, and Sagittarius...), nor to the alternative Hindu system (Mercury, Sun, Moon in Virgo...). The source of this system is unknown.

Table 10. The tableof Decans

\begin{tabular}{|c|c|c|}
\hline Zodiac sign & $\begin{array}{l}1^{\text {st }} \text { variant } \\
(\text { scale VI) }\end{array}$ & $\begin{array}{l}2^{\text {nd }} \text { variant } \\
\text { (scale VII) }\end{array}$ \\
\hline \multirow{3}{*}{ Aries } & Mercury & Mars \\
\hline & Sun & Sun \\
\hline & Venus & Jupiter \\
\hline \multirow{3}{*}{ Taurus } & Mars & Venus \\
\hline & Moon & Mercury \\
\hline & Saturn & Saturn \\
\hline \multirow{3}{*}{ Gemini } & Moon & Mercury \\
\hline & Saturn & Venus \\
\hline & Jupiter & Saturn \\
\hline \multirow{3}{*}{ Cancer } & Mercury & Moon \\
\hline & Venus & Mars \\
\hline & Mars & Jupiter \\
\hline \multirow{3}{*}{ Leo } & Moon & Sun \\
\hline & Saturn & Jupiter \\
\hline & Jupiter & Mars \\
\hline \multirow{3}{*}{ Virgo } & Mercury & Mercury \\
\hline & Venus & Saturn \\
\hline & Mars & Venera \\
\hline \multirow{3}{*}{ Libra } & Moon & Venus \\
\hline & Saturn & Saturn \\
\hline & Jupiter & Mercury \\
\hline \multirow{3}{*}{ Scorpio } & Mercury & Mars \\
\hline & Sun & Jupiter \\
\hline & Venus & Moon \\
\hline \multirow{3}{*}{ Sagittarius } & Mars & Jupiter \\
\hline & Moon & Mars \\
\hline & Saturn & Sun \\
\hline
\end{tabular}

\begin{tabular}{|l|l|c|}
\hline \multirow{4}{*}{ Capricornus } & Jupiter & Saturn \\
\cline { 2 - 3 } & Mercury & Venus \\
\cline { 2 - 3 } & Sun & Mercury \\
\hline \multirow{3}{*}{ Aquarius } & Venus & Saturn \\
\cline { 2 - 3 } & Mars & Mercury \\
\cline { 2 - 3 } & Moon & Sun \\
\hline \multirow{3}{*}{ Pisces } & Saturn & Mercury \\
\cline { 2 - 3 } & Jupiter & Mars \\
\cline { 2 - 3 } & Mercury & Saturn \\
\hline
\end{tabular}

\subsection{Alidade}

The alidade is used to measure the angles of altitudes of celestial and terrestrial objects. In addition to its direct application, the alidade of this instrument performed two other important functions. For example, one half of the alidade is divided into 60 equal divisions (at the right of the photo) to use with the sine scale (see above). The same role is played by the saw-teeth near the central hole.

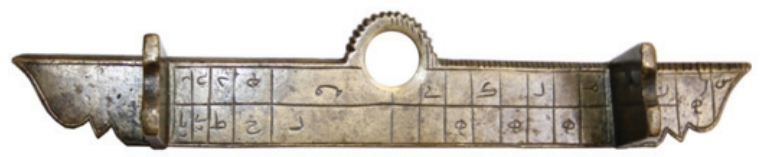

Fig. 13. The Alidade

(C) The State Museum of Oriental Art, Moscow

The second half of the alidade (on the left) could be used as a sundial, the sighting plate on the right functioning as the gnomon. Before noon, the divisions 7 to 11 hours are used (in the lower row from right to left): in the afternoon the divisions 2 to 6 (in the upper row from left to right).

\section{The enigmas in the astrolabe}

This astrolabe throws up several enigmas. First, why was the astrolabe belonging to Mīrzā Bāysunghur copied at Lahore in 1587? It appears that sometimes certain very valuable astrolabes are copied to be used as gifts. It is reported that Shāh Abbās of Iran had with him an astrolabe belonging to Ulugh Beg; when the Mughal Emperor Jahāngīr requested him for it, the Shāh generously gifted it to him, but got a copy made for himself (Sarma, 2011, p.112). 
Obviously the astrolabe originally belonging to Mīrzā Bāysunghur was in Lahore in the latter half of the sixteenth century. It was considered very exceptional either because of its design or because of the person who originally owned it. Therefore, a patron ordered a copy for himself, on which he desired an inscription stating expressly that it was the copy of the astrolabe belonging to Mīrzā Bāysunghur. This copy is the Moscow Astrolabe.

However, the patron was not fortunate in his choice of artisans for copying the astrolabe. At least two artisans are involved in producing the copy. One apparently had some experience in making astrolabes. He made the rete and the first plate. The rete is made reasonably correctly, but the ecliptic ring is not divided in single degrees. The plate he made carried projections for the latitude of Mecca at $21^{\circ} 40^{\prime}$ on one side and projections for multiple horizons on the other side. The projections for Mecca are done reasonably correctly, but the duration of the longest day engraved on the plate was not correct. He may also have made the alidade.

The rest of the astrolabe, namely the mater and four plates are made by a person who did not understand the functions of the various components of the astrolabe. As we have explained above, he spoiled the symmetrical structure of the geographical gazetteer on the inner side of the mater. On the back of the mater, in the upper left quadrant he drew 67 horizontal parallels instead of 60. On the upper right quadrant, he drew the table of triplicities upside down, and so on. He must have had the original astrolabe of Mīrzā Bāysunghur in front of him, but must have thought that it was not necessary to copy it exactly.

One would have thought that normally the master astrolabe maker would prepare the mater and the rete and that his assistants would make the plates. It is an enigma why this did not happen with the Moscow Astrolabe.

\subsection{The Greenwich Astrolabe}

Searching for similar astrolabes, we came across an astrolabe made by Yūsuf ibn Hājjī al-Jīlānī in 1522 at Gilan near the Caspian Sea. It is now with the National Maritime Museum, Greenwich (Charette, 2005, pp. 220-223). We shall call it the "Greenwich Astrolabe" in the following discussion.

There are several similarities between the two astrolabes at Greenwich and Moscow.

1. The throne (see Fig. 1 and Fig. 14) and the alidade are identically shaped.

2. The latitude plates have a hole on the lower part of the meridian line and the inner surface of the mater has a knob at the same place.

3. One side of the first plate is made for the latitude of Mecca and the other side for multiple horizons.

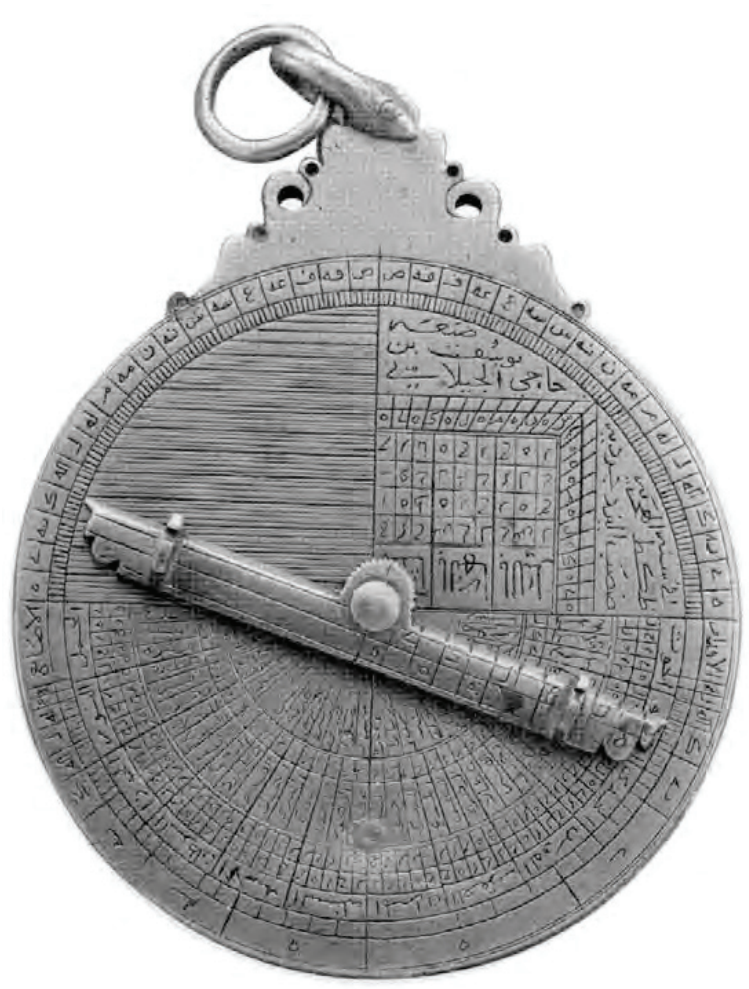

Fig. 14. Back of the Greenwich Astrolabe (Charette, 2005, p. 221) 
4. The horizon plate has 4 extra half-horizons for latitudes $66^{\circ} 30^{\prime}, 72^{\circ}, 78^{\circ}$ and $84^{\circ}$, together with labels. Besides the four labels related to these four latitudes, the Moscow astrolabe has three more inscriptions engraved outside the circle of equator.

5. In the geographical gazetteer in both astrolabes, the cities are listed from Baghdad onwards and the first 15 cities are identical. More important, Gilan occurs in both the gazetteers.

6. On the back, the shadow square is drawn in the upper right quadrant and inside the shadow square, the table of triplicities in engraved upside down.

7. The astrological table in the lower half is almost the same, the main difference being the symbols used in the Moscow astrolabe for the planets ruling the decans in row VI.

But the rete differs in the two astrolabes. Charette states that the rete in the Greenwich Astrolabe is not original but a replacement (Charette, 2005, p.220). It is likely the original rete of the Greenwich Astrolabe was shaped like the rete in the Moscow Astrolabe.

Is it the Greenwich Astrolabe made by Yusuf ibn Hājjī al-Jīlānī in 1522 which was copied at Lahore in 1587? Then the astrolabe maker of Lahore would not have called his production (i.e. the Moscow Astrolabe) a copy of Mīrzā Bāysunghur's astrolabe. Therefore, we have to assume that Mīrzā Bāysunghur's astrolabe looked more or less like the astrolabe of 1522 made by Yusuf ibn Hājjī al-J̄̄lānī, but was different from it. We cannot, at this stage, say how these two astrolabes are related in time or space and why they have so many similarities.

\subsection{Other precursors Moscow astrolabe}

In the Davids Samling, Copenhagen, there is an astrolabe made by Muhammad ibn $\mathrm{Ja}^{\mathrm{c}}$ far ibn 'Umar al-Așturlābī called Jalāl in 830 Hijra (AD 1426-27). It is described and illustrated by David A. King as "An Astrolabe for the Sultan Ulugh Beg” (King, 2005, pp. 754-765). On the kurs $\bar{\imath}$ is a long inscription from which the name of the dedicatee has been erased. But King is of the view that that the astrolabe must have been made for Ulugh Beg.

On the inner side of the mater is engraved the tablet of horizons. As in the Moscow astrolabe, here also there are additional half-horizons for latitudes above $66 ; 30^{\circ}$ with explanatory labels. Very likely that the horizon plate in the Greenwich astrolabe made by Yusuf ibn Hājjī al-J̄̄lānī in 1522 was copied from the horizon plate of the Copenhagen astrolabe, but the labels have not been completely copied. Likewise, the horizon plate in the original astrolabe made for Mìrzā Bāysunghur must have been copied from the Copenhagen astrolabe of 1426; the same was copied imperfectly in the Moscow astrolabe.

Some parts of the labels in the Moscow astrolabe are incomprehensible. A comparison with the labels in the Copenhagen astrolabe shows that in the Moscow astrolabe some of the labels are engraved at wrong places. There are other elements, reminiscent of Moscow astrolabe; for example, table of the excess of revolution and the decorative holes on the kursi $\bar{\imath}$ which are enclosed in curls.

If we search for still earlier parallels, we find similar half-horizons for latitudes above $66 ; 30^{\circ}$ in the astrolabe made by $\mathrm{Ja}^{\mathrm{c}}$ far ibn ${ }^{\mathrm{c}} \mathrm{Umar}$ ibn Dawlatshah al-Kirmān̄i in 774 Hijra (AD 1372) (Gibbs, Saliba, 1984, pp.64-65). In addition, the 20 localities listed in the gazetteer match with those on the Moscow astrolabe; in both astrolabes, there are decorative holes enclosed by curls on the kursī.

All predecessors of the Moscow astrolabe have similar sets of astrological tables as well. 


\subsection{Reconstruction of Mīrzā Bāysunghur's Astrolabe}

In the light of the preceding discussion, we can attempt to reconstruct the original astrolabe that was made for Mīrzā Bāysunghur.

1. The throne would be like the throne in the Moscow Astrolabe and in the Greenwich Astrolabe.

2. The limb on the front carries a degree scale as in the Moscow Astrolabe.

3. The rete would be like the rete in the Moscow Astrolabe.

4. The first plate would be like plate I in the Moscow Astrolabe (and also like the first plate in the Greenwich Astrolabe) with horizons on one side and projections for the latitude of Mecca on the other.

5. Other plates would carry correct projections for 8 different latitudes.

6. The geographical gazetteer would be like the same in the Moscow astrolabe but without the distortions.

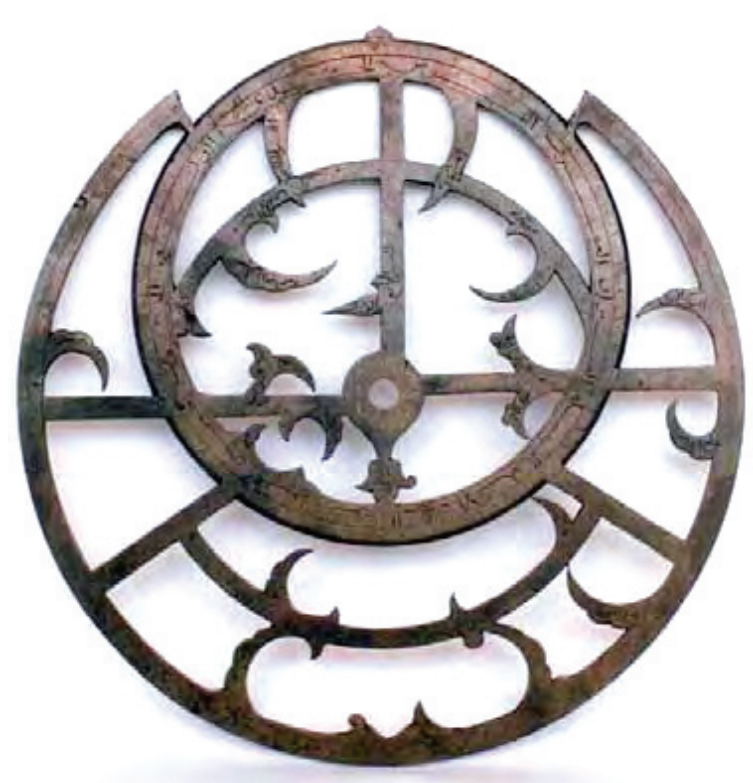

Fig. 15. Rete in the astrolabe of 1567 by Allāhdād (photo courtesy Salar Jung Museum)
7. The back would be like the back on the Moscow Astrolabe without the distortions; that is to say, like the back on the Greenwich Astrolabe: sine quadrant in the upper left, single shadow square on the upper right, inside which are accommodated a table of triplicities and a "calendar table"; a large astrological table in the lower half, but with the unusual symbols for planets in row VI.

\subsection{Mīrzā Bāysunghur's Astrolabe in Lahore}

This astrolabe must have been in Lahore in the second half the sixteenth century and was considered an exceptional astrolabe. Therefore, a patron ordered a copy to be made. Because of the incompetence and carelessness of the astrolabe makers, the copy contains many distortions as detailed above.

This astrolabe also attracted the attention of Allāhdād, the founder of the famous Lahore Family of astrolabe makers, in particular the rete. This rete consists of the Capricorn circle and ecliptic circle which are held together by the meridian bar and east-west bar, both with counter-

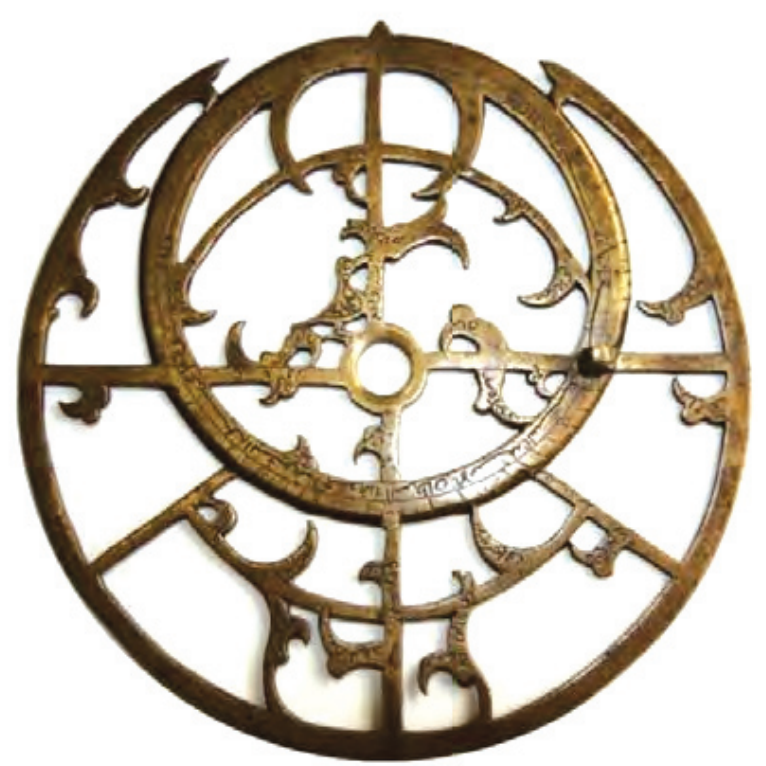

Fig. 16. Rete in the Moscow astrolabe of 1587 (C) The State Museum of Oriental Art, Moscow 
changes. Small sections of the equator ring are shown in the upper and lower halves. The star pointers generally have the shape of tiger's claws; one or two lobes are added to some of these star pointers.

In his astrolabe of 1567 (Salar Jung Museum, Hyderabad), Allāhdād imitated this rete. However, in his second astrolabe (Museum of the History of Science, Oxford), Allāhdād has an entirely different type of rete, where the star pointers are joined by an ornate floral tracery. This style of floral rete was adopted in almost all the astrolabes made by the descendants of Allāhdād.

However, the type of rete to be found in the Moscow Astrolabe and in Allāhdād's astrolabe of 1567, appears in two more astrolabes of Lahore: an unsigned and undated astrolabe which can be attributed to Allāhdād (National Maritime Museum, Greenwich) and an undated astrolabe by Allāhdād's grandson Muhammad Muqīm (Lahore Museum). There are slight differences in the retes of these three astrolabes and in the rete of the Moscow astrolabe, but the basic design is the same and the number of star pointers is roughly the same.

Thus, this defective copy of Mīrzā Bāysunghur's Astrolabe solves at least one enigma. Allāhdād and his descendants equipped their astrolabes with beautiful floral retes. Why did they have, in the astrolabe of 1567 and two others, retes so radically different from their standard floral retes? The Moscow astrolabe provides an answer to this question. Because the astrolabe of Mīrzā Bāysunghur enjoyed a great prestige in contemporary circles, they imitated the rete in a few cases.

\section{ACKNOWLedGements}

Grateful thanks are due to Maria Kullanda, Irina Sheptunova, and Basil Cherkasov of the State Museum of Oriental Art, Moscow, for allowing the first author to study the Moscow Astrolabe; to Professor Paul Kunitzsch (Munich) for his kind advice on the Arabic star names; and to Professor Mohammad Bagheri (Tehran), to Mikhail Palenko (Moscow) and Dr. Owen T. Cornwall (New York) for their ready help in translating the Arabic and Persian passages; and to the unknown referee for his helpful suggestions.

\section{REFERENCES}

Ackermann, Silke. Astrological Scales on the National Maritime Museum Astrolabes, in: Van Cleempoel (ed), Astrolabes at Greenwich. A Catalogue of the Astrolabes in the National Maritime Museum, Greenwich, 2005, pp. 73-89.

Allen, Richard Hinckley. Star-names and their meanings, New York, Leipzig [etc.],1899; reprint 1963: Star-Names: Their Lore and Meaning. URL: https:// archive.org/details/starnamesandthe00allegoog.

Bakikhanov, Abbas-Kuli-Agha. Giulistan-i Iram, A History of Shirvan \& Daghestan.The Third Period. From the invasion of the Mongols to the accession of the Safavid dynasty to the Persian throne - from 656 AH (1258) to $906 \mathrm{AH}$. (1501) with a brief listing of the Shirvan Shahs, and rulers. Bunijatova Z. M. (ed), Baku, 1991. URL: http:/www.vostlit.info/Texts/rus2/Bakihanov/ frametext3.htm (in Russian).

Charette, François. Catalogue of Eastern Astrolabes, in: Van Cleempoel (ed), Astrolabes at Greenwich. A Catalogue of the Astrolabes in the National Maritime Museum, Greenwich. 2005, pp. 210-319.

Chenakal, V. L. Quadrants and Astrolabes, in: L. E. Maystrov (ed), Scientific instruments. Instruments of historic significance, Moscow: Nauka, 1968.

Encyclopaedia Iranica, Vol. IV, 1990.

Gibbs, Sharon L., Henderson, Janice A., Price, Derek de Solla. The Computerized Checklist of Astrolabes. Yale University, New Haven, 1973.

Gibbs, Sharon \& Saliba George. Planispheric Astrolabes from the National Museum of American History. Smithsonian Institution Press, Washington, 1984.

Jackson, Peter. The Cambridge History of Iran. Vol. VI: The Timurid and Safavid Periods, 1986.

Kaye, G. R. The Astronomical Observatories of Jai Singh, Calcutta, 1918; reprint, New Delhi, 1982.

Kennedy E.S. A Survey of the Islamic astronomical tables. Trans. Amer. Philos. Soc., V. 46, pt. 2, 1956. 
al-Khwārizmī, Muhammad ibn Mūsā. Mathematical treatises, ed. G.P. Matvievskaja, Tashkent, 1983 (in Russian).

King, David. In Synchrony with the Heavens: Studies in Astronomical Timekeeping and Instrumentation in Medieval Islamic Civilization. Vol. 2: Instruments of Mass Calculation (Studies X-XVIII), Leiden, Boston: Brill Academic Publishers, 2005.

Kunitzsch, P. \& Smart, T. A Dictionary of Modern Star Names. A Short Guide to 254 Star Names and Their Derivations, Sky Publishing, USA, 2006.

Morrison, James E. The Astrolabe. Janus, 2007.

Pingree, David. Eastern Astrolabes. Adler Planetarium \& Astronomy Museum. Chicago, 2009.
Sarma, Sreeramula Rajeswara. Astronomical Instruments in the Salar Jung Museum, Salar Jung Museum, Hyderabad, 1996.

Sarma, Sreeramula Rajeswara.The Lahore family of Astrolabists and their Ouvrage, in: idem, The Archaic and the Exotic: Studies in the History of Indian Astronomical Instruments, New Delhi, 2008, pp. 199-222.

Sarma, Sreeramula Rajeswara. A Bilingual Astrolabe from the Court of Jahāngīr, Indian Historical Review, 38.1 (June 2011) 77-117.

Smirnov, S. V. Astrolabe at the Moscow Museum of the Culture of Oriental Peoples in: Studies on the History, of Astronomy, Vol. X, Moscow, 1969, pp. 311-330 (in Russian). 